NNTERIM REPORT

THE INFLUENCE OF COMPOSITION ON ENVIRONMENTAL EMBRITTLEMENT OF IRON ALUMINIDES

RECEIVED

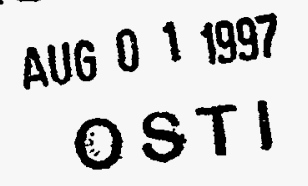

July 1,1996

Reasearch sponsored by the U. S. Department of Energy

Office of Fossil Energy

Advanced Research and Technology Development Materials Program

Report Prepared by

D. A. Alven and N. S. Stoloff

Rensselaer Polytechnic Institute

Materials Science and Engineering Department

Troy, NY 12180-3590

under

Subcontract No. 19x-SF521C

for

OAK RIDGE NATIONAL LABORATORY

Oak Ridge, Tennessee 37831

managed by

MARTIN MARIETTA ENERGY SYSTEMS, INC.

for the

U.S. Department of Energy

under Contract No. DE-AC05-840R21-400 
This report has been reproduced directly from the best available copy.

Available to DOE and DOE contractors from the Office of Scientific and Technical information, P.O. Box 62, Oak Ridge, TN 37831; prices available from (423) 576-8401.

Available to the public from the National Technical Information Service, U.S. Department of Commerce, 5285 Port Royal Rd., Springfield, VA 22161.

This report was prepared as an account of work sponsored by an agency of the United States Government. Neither the United States Government nor any agency thereof, nor any of their employees, makes any warranty, expressed or implied, or assumes any legal liability or responsibility for the accuracy, completeness, or usefulness of any information, apparatus, product, or process disclosed, or represents that its use would not infringe privately owned rights. Reference herein to any specific commercial product, process, or service by trade name, trademark, manufacturer, or otherwise, does not necessarily constitute or imply its endorsement, recommendation, or favoring by the United States Government or any agency thereof. The views and opinions of authors expressed herein do not necessarily state or reflect those of the United States Government or any agency thereof. 


\section{DISCLAIMER}

Portions of this document may be illegible in electronic image products. Images are produced from the best available original document. 


\title{
INTERIM REPORT \\ THE INFLUENCE OF COMPOSITION ON ENVIRONMENTAL EMBRITTLEMENT OF IRON ALUMINIDES
}

July 1,1996

\author{
Report Prepared by \\ D. A. Alven and N. S. Stoloff \\ Rensselaer Polytechnic Institute \\ Materials Science and Engineering Department \\ Troy, NY 12180-3590 \\ under \\ Subcontract No. 19x-SF521C \\ for \\ OAK RIDGE NATIONAL LABORATORY \\ Oak Ridge, Tennessee 37831 \\ managed by \\ MARTIN MARIETTA ENERGY SYSTEMS, INC. \\ for the \\ U.S. Department of Energy \\ under Contract No. DE-AC05-840R21-400
}


Research sponsored by the U. S. Department of Energy, Fossil Energy Advanced Research and Technology Development Materials Program, DOE/FE AA 151010 , Work Breakdown Structure Element RPI-2

\begin{abstract}
The effects of water vapor in air and hydrogen gas on the tensile and fatigue crack growth behavior of $\mathrm{Fe}_{3} \mathrm{Al}$ alloys have been studied at room temperature. $\mathrm{Fe}-28 \mathrm{a} \% \mathrm{Al}$ $5 \mathrm{a} \% \mathrm{Cr}$ alloys to which either $\mathrm{Zr}$ alone or $\mathrm{Zr}$ and $\mathrm{C}$ have been added have been tested in controlled humidity air environments as well as in $1.3 \mathrm{~atm}$ hydrogen or oxygen gas.and in vacuum. As with other $\mathrm{Fe}_{3} \mathrm{Al}$ alloys, oxygen produces the lowest crack growth rates as well as the highest critical stress intensities and tensile ductility in each of the alloys tested. However, while $\mathrm{Zr}$ lowers crack growth rates in the Paris regime, there is no apparent beneficial effect on crack growth thresholds. Hydrogen gas also produces unusual results. While crack growth rates are very high in hydrogen in the Paris regime for all alloys, hydrogen only lowers the crack growth threshold relative to air in ternary $\mathrm{Fe}-28 \mathrm{Al}-5 \mathrm{Cr}$; it does not lower the threshold in the $\mathrm{Zr}$-containing alloys. It was found that decreased test frequency leads to increased crack growth rates in a $\mathrm{Zr}$-containing alloy which points to a moisture-induced embrittlement mechanism responsible for the higher crack growth rates in air. Fracture path tends to be insensitive to environment for each alloy.
\end{abstract}

\title{
1 INTRODUCTION
}

Iron aluminides are currently being considered for use in applications where excellent corrosion resistance, moderate strength at temperatures up to $500^{\circ} \mathrm{C}$, and low cost are desired. Binary iron aluminides do not possess high ductility at room temperature in air; however, when tested in vacuum or gaseous oxygen environments iron 
aluminides have demonstrated ductility of greater than $10 \%(1,2,3)$. This indicates that $\mathrm{Fe}_{3} \mathrm{Al}$ is an inherently ductile material and the low ductility in air is due to an environmental interaction.

The purpose of this research was to examine the changes in mechanical properties of several $\mathrm{Fe}_{3} \mathrm{Al}, \mathrm{Cr}$ intermetallic alloys in various environments. The tensile behavior and fatigue crack growth resistance were examined and the resulting data will be discussed in the light of the role of hydrogen in embrittlement of the iron-aluminum alloys.

\section{EXPERIMENTAL PROCEDURE}

\subsection{Alloy Composition and Heat Treatment}

Four alloys were used in this study, an $\mathrm{Fe}-28 \%$ al-5\% $\mathrm{Cr}$ alloy designated ternary, an $\mathrm{Fe}-28 \%$ al-5\% $\mathrm{Cr}-1 \% \mathrm{Zr}$ alloy designated $1 \% \mathrm{ZrC}$, and two $\mathrm{Fe}-28 \% \mathrm{Al}-5 \% \mathrm{Cr}-0.5 \% \mathrm{Zr}$ alloys, one with carbon and one without, designated $0.5 \% \mathrm{ZrC}$ and $0.5 \% \mathrm{Zr}$, respectively. All the alloys are ordered $\mathrm{Fe}_{3} \mathrm{Al}$ type intermetallics. The compositions of these alloys are shown in Table 1. All alloys were fabricated at Oak Ridge National Laboratory (ORNL) by vacuum induction melting, extrusion to $1.27 \mathrm{~cm}$ square bar, and hot rolling to the final thickness. The plate thickness of $1 \% \mathrm{Zr}$ used in compact tension specimens was $4.0 \mathrm{~mm}$, while the final plate thickness for the other alloys was $4.75 \mathrm{~mm}$. For tensile test the material was extruded to a $1.08 \mathrm{~cm}$ diameter bar.

Due to the texture imparted by the rolling process the terms longitudinal, short transverse, and long transverse will be used to indicate the three perpendicular planes relative to the rolling direction. These planes are illustrated in Fig. 2.1, where the longitudinal plane is the rolling direction, and the short and long transverse planes are the remaining planes. 
All alloys used in this study had the same B2 order. The annealing parameters for the $\mathrm{B} 2$ order consisted of a $700^{\circ} \mathrm{C}$ anneal for 1 hour with a mineral oil quench which was then repeated.

Metallography

Metallography was performed on all alloys to examine the grain structure. Samples from the plates were sectioned using a cut-off wheel in the longitudinal, short and long transverse directions and then mounted in epoxy molds. Polishing was

TABLE 1

Composition and Grain Size of Iron -Aluminide Alloys

Atomic \%

\begin{tabular}{lllll}
\hline & Ternary & $1 \% \mathrm{Zr}$ & $0.5 \% \mathrm{ZrC}$ & $0.5 \% \mathrm{Zr}$ \\
\hline $\mathrm{Fe}$ & 67 & 65.95 & 66.45 & 66.5 \\
$\mathrm{Al}$ & 28 & 28 & 28 & 28 \\
$\mathrm{Cr}$ & 5 & 5 & 5 & 5 \\
$\mathrm{Zr}$ & & 1 & 0.5 & 0.5 \\
$\mathrm{C}$ & & 0.05 & 0.05 & \\
Grain Size & \multirow{2}{*}{$180 \mu \mathrm{m}$} & partially & partially & partially \\
& & recrystallized & recrystallized & recrystallized \\
\hline
\end{tabular}

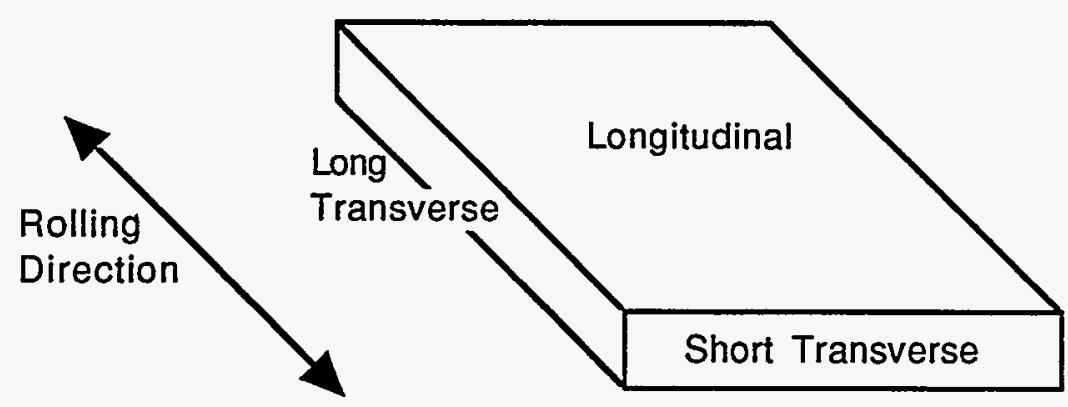

Fig. 2.1 Directional planes of a rolled plate. 
performed by first lapping the samples on a Lapmaster then on a water lubricated polishing wheel with 600 grit paper. They were then polished on cloth covered wheels containing $15 \mu \mathrm{m}$ and $9 \mu \mathrm{m}$ diamond paste and finished on a felt covered wheel with $0.3 \mu \mathrm{m}$ alumina slurry with $10 \%$ oxalic acid. The metallographic specimens were then etched in glycerigia ( $30 \mathrm{ml}$ glycerin, $30 \mathrm{ml} \mathrm{HCl}, 10 \mathrm{ml} \mathrm{HNO}_{3}$ ) until the grain structure became visible. All photomicrographs were produced on a polarizing metallograph using Polaroid type 55 film.

\subsection{Tensile Test}

Tensile tests were performed on the ternary and $0.5 \% \mathrm{ZrC}$ alloys in laboratory air, oxygen and hydrogen and on the $0.5 \% \mathrm{Zr}$ and $1 \% \mathrm{ZrC}$ alloys in laboratory air. Tensile specimens were machined from rods with a diameter of $1.12 \mathrm{~cm}$, or from plate material with a thickness of $0.5 \mathrm{~mm}$ with the specimen geometry shown in Fig. 2.2. The tension specimens were polished to a $0.3 \mu \mathrm{m}$ finish and ultra-sonically cleansed in acetone prior to testing.

The rod specimens were tested in a servo-hydraulic MTS machine fitted with a vacuum chamber, which allowed for testing in air vacuum or any inert gas. The samples were griped using a split-type wedge grip shown in Fig. 2.3. The strain rate used in all test was $3 \times 10^{-4} / \mathrm{sec}$. All test were conducted at room temperature. One specimen was tested for each environment due to the limited availability of material. The plate specimens were tested on a screw driven Instron 4200 at the same strain rate.

When testing in oxygen or hydrogen gas, the environmental chamber was first evacuated to $<6.6 \times 10^{-4} \mathrm{~Pa}$ using a diffusion pump fitted with a liquid nitrogen cold trap. The appropriate gas was then admitted to the chamber at a pressure of $2300 \mathrm{~Pa}$ over atmospheric pressure for 1 hour prior to testing. All gases used were of Ultra-High Purity Grade, with a maximum water vapor concentration of $3 \mathrm{ppm}$. 

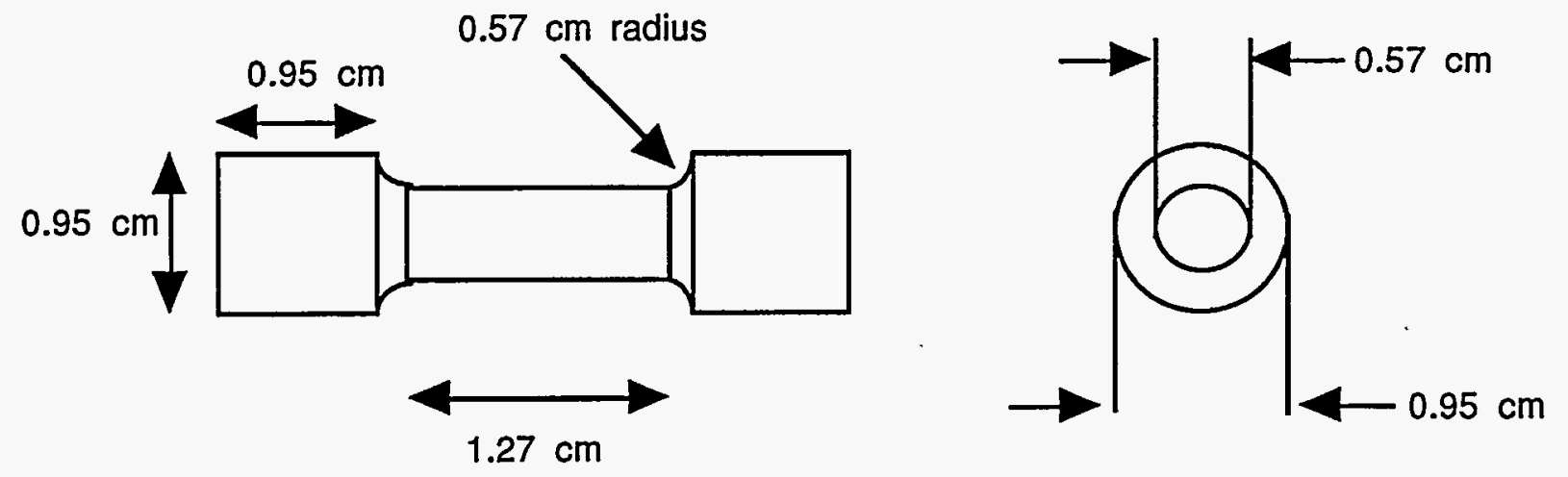

(a)

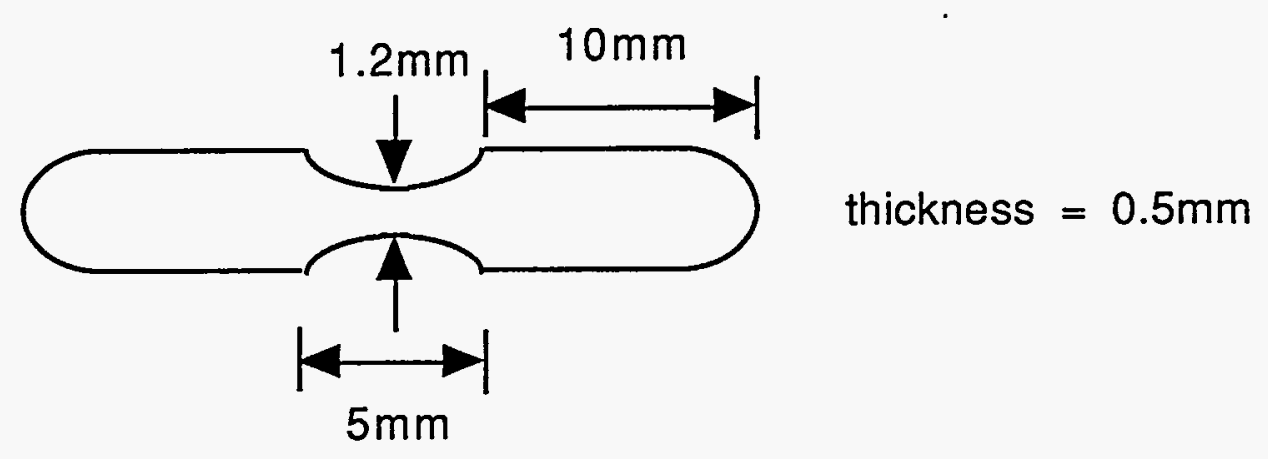

(b)

Fig. 2.2 Tensile specimen geometry for (a) the ternary and $0.5 \% \mathrm{ZrC}$, (b) the $0.5 \% \mathrm{Zr}$ and $1 \% \mathrm{ZrC}$ alloys. 


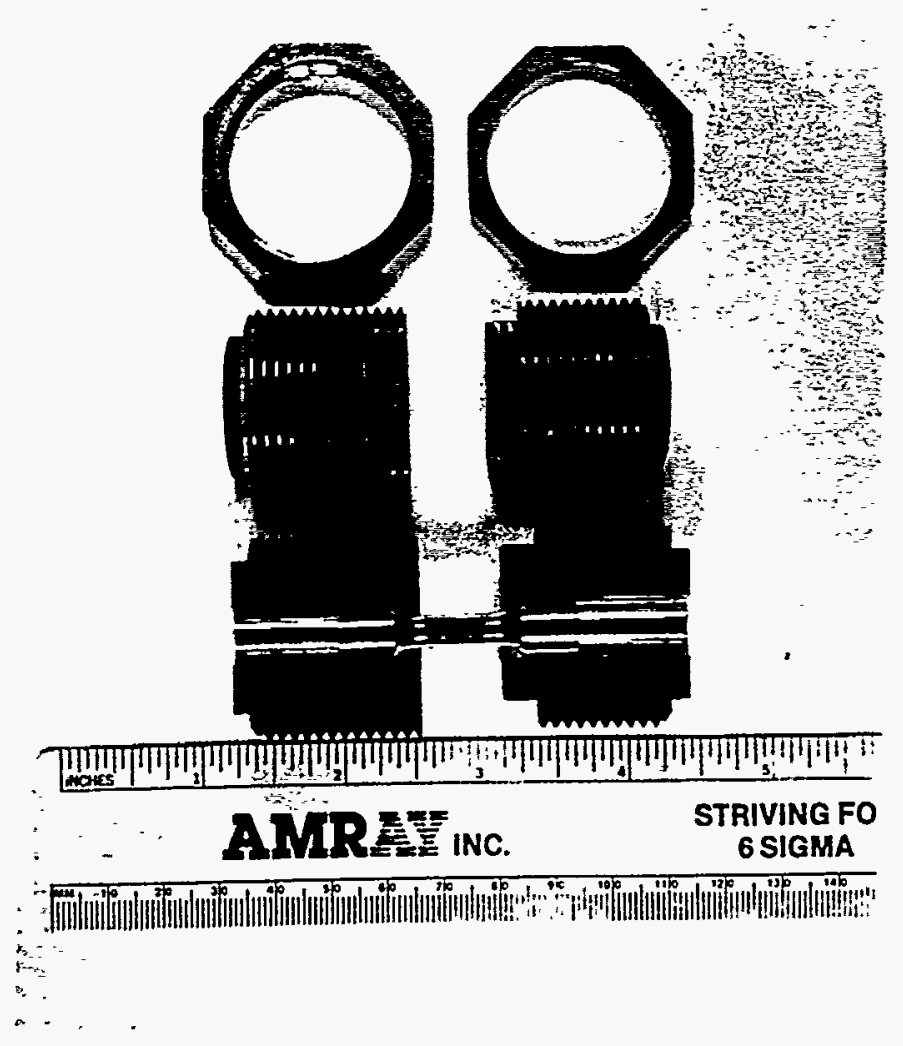

Fig. 2.3. Wedge grip used in tensile testing. 


\subsection{Fatigue Crack Growth Tests}

Fatigue crack growth test were performed on the ternary, $0.5 \% \mathrm{ZrC}, 0.5 \% \mathrm{Zr}$, and $1 \% \mathrm{ZrC}$ alloys in the $\mathrm{B} 2$ ordered state. All alloys were tested at room temperature in 1.3 atm hydrogen gas and $1.3 \mathrm{~atm}$ oxygen gas. The ternary alloy was tested in laboratory air . while all other alloys were tested in constant humidity environments of $21 \%, 48 \%$, and $81 \%$ relative humidity $(\mathrm{rH})$.

When testing in a gaseous environment the procedure previously described in section 2.2, for tensile tests, was used. For testing in vacuum the chamber was evacuated to $<8 \times 10^{-7} \mathrm{~Pa}$. For constant humidity tests compressed air was bubbled through a closed beaker containing an aqueous solution of potassium acetate, potassium thiocyanate, or ammonium chloride which produced $21 \% \mathrm{rH}, 48 \% \mathrm{rH}$ and $81 \% \mathrm{rH}$, respectively.

Compact tension specimens were used for all fatigue tests. The specimens were cut by electro discharge machining such that the crack growth direction was perpendicular to the rolling direction. Fig. 2.4 shows the specimen geometry. All specimens were polished to a $0.3 \mu \mathrm{m}$ finish and ultra-sonically cleansed in acetone prior to testing.

Crack length was monitored using the d.c. potential drop method. A Hewlett Packard power supply supplied a 10 amp current to the specimen via two current leads positioned $11.5 \mathrm{~mm}$ on either side of the machined notch. The current was monitored by an IBM PC computer through a Metrabyte 12 bit analog to digital converter via a resistive shunt. The potential across the unbroken ligament was measured by two voltage probes located $2.5 \mathrm{~mm}$ on either side of the notch. The leads were connected to the compact tension specimen brazing them into short holes drilled into the front face.

Calibration curves were created to relate the crack length to the potential drop by optically measuring the crack length with a traveling microscope. The system was able to resolve changes in the crack length of $40 \mu \mathrm{m}$. 


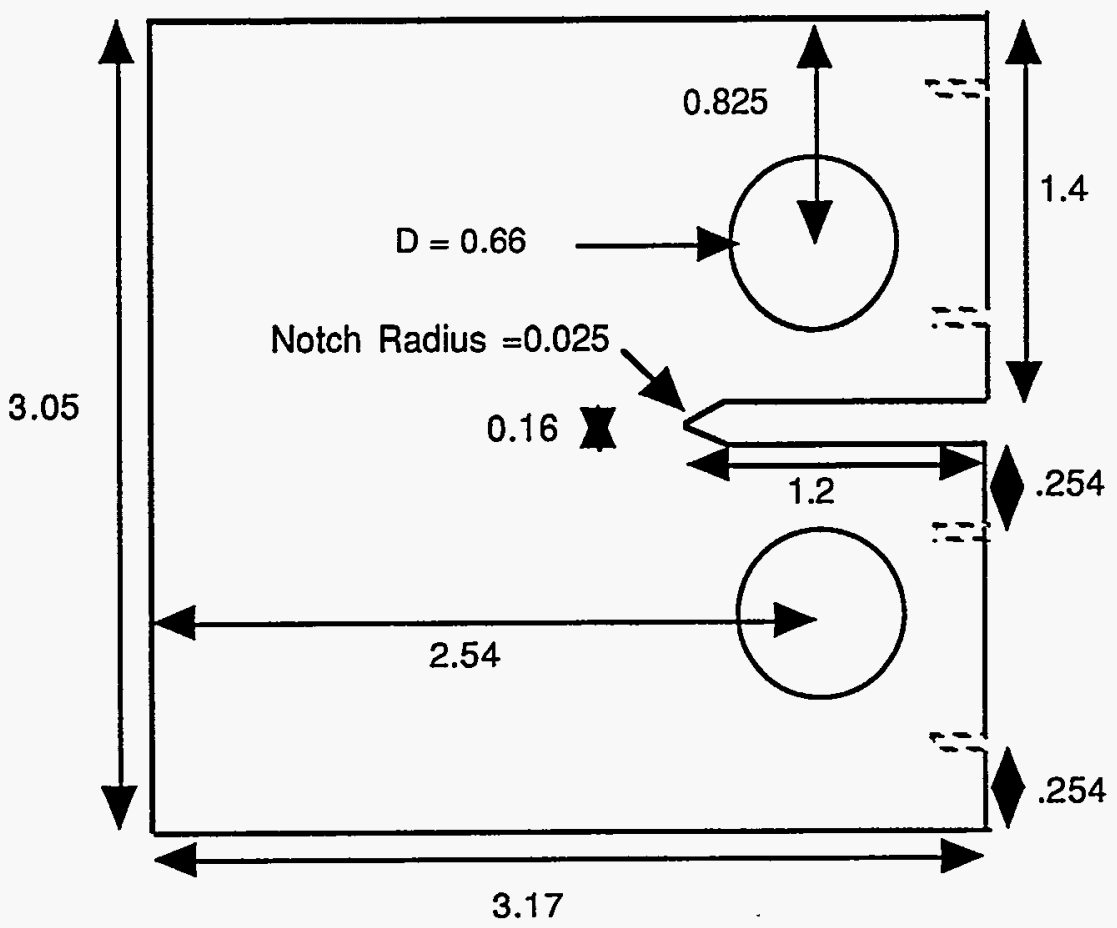

All dimensions in centimeters

Fig. 2.4. Geometry of the compact tension specimens.

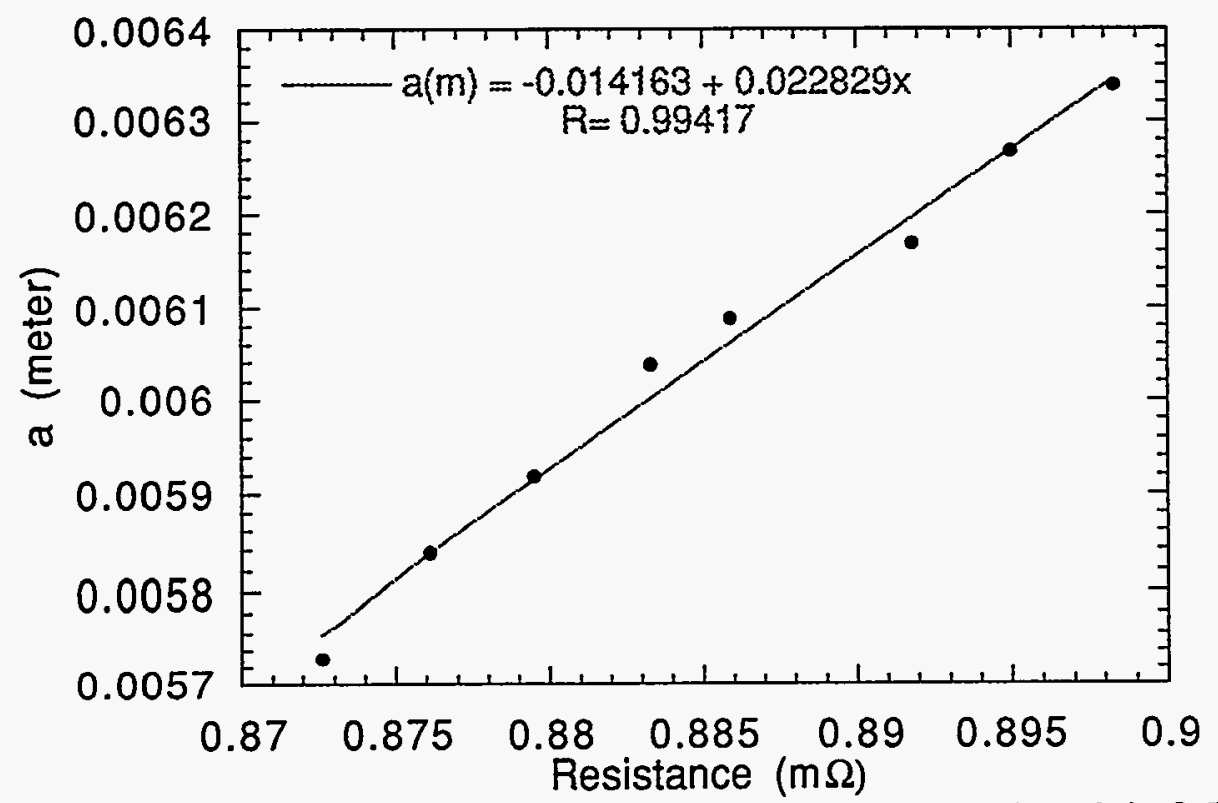

Fig. 2.5. Calibration curve relating the resistance to the crack length in $0.5 \% \mathrm{ZrC}$. 
The optical microscope, which had an accuracy of $20 \mu \mathrm{m}$, determined the accuracy of the crack measurements. An example of a calibration curve obtained for the $0.5 \% \mathrm{ZrC}$ alloy is shown in Fig. 2.5.

The load frame used was an MTS servo-hydraulic machine with a $22205 \mathrm{~N}$ load cell. Tests were run in load control utilizing a sawtooth waveform at a frequency of $20 \mathrm{~Hz}$ and an $\mathrm{R}$ ratio $\left(\sigma_{\min } / \sigma_{\max }\right)$ of 0.5 . The effect of frequency was investigated by fatiguing $0.5 \% \mathrm{ZrC}$ at $20 \mathrm{~Hz}, 2 \mathrm{~Hz}, 0.2 \mathrm{~Hz}$ and $0.08 \mathrm{~Hz}$.

Software written for a PC allowed a fully automated test procedure. The P.C recorded load applied to the specimen, current, and voltage then calculated crack length, crack growth rate $(\mathrm{da} / \mathrm{dN})$, and stress intensity range $(\Delta \mathrm{K})$. The calculated values were then used to produce the appropriate waveform. This digital waveform was then converted to analog and sent to the MTS as the load control input for the hydraulic system.

All parameters of the fatigue crack growth test followed ASTM E-647 (4) procedures. The fatigue crack growth testing procedure was as follows:

1) Precracking of the CT specimen by fatiguing in 20000 cycle increments at stress intensity levels increasing be $0.5 \mathrm{MPa} / \mathrm{m}$ until crack initiation was observed.

2) $\mathrm{A} \Delta \mathrm{K}$-increasing procedure was employed until the crack had grown $1.0 \mathrm{~mm}$ from the $5.5 \mathrm{~mm}$ machined notch before data collection began.

3) A load shedding routine was then used to reduce the da/dN values back down to approximately $5 \times 10^{-9} \mathrm{~m} /$ cycle to measure crack growth rates in the threshold region. This was the lowest growth rates that could be accurately and conveniently measured.

4) The $\Delta \mathrm{K}$-increasing routine was then continued until failure. Throughout the testing procedure the R-ratio was held at 0.5 and total crack lengths were measured at crack growth intervals of $0.05 \mathrm{~mm}$.

In accordance with ASTM E-647, the following equation for calculating stress intensity range, $\Delta \mathrm{K}$, was used: 


$$
\Delta \mathrm{K}=\frac{\Delta \mathrm{P}}{\mathrm{B} \sqrt{\mathrm{W}}}\left(0.886+4.64 \alpha-13.32 \alpha^{2}+14.72 \alpha^{3}-5.64 \alpha^{4}\right) \quad \text { Eq. } 1
$$

In Eq. $1, \Delta \mathrm{P}$ is the cyclic load range, $\mathrm{B}$ is the specimen thickness, $\mathrm{W}$ is the specimen length from the edge to the center of the load-pin holes, and alpha is the ratio of crack length to $\mathrm{W}$. The crack length is always measured from the center of the load-pin holes to the crack tip.

\subsection{Microscopy}

\subsubsection{Scanning Electron Microscopy}

All specimen fracture surfaces were examined in a JOEL-840 scanning electron microscope (SEM) after failure. The fracture mode (cleavage, intergranular, dimpled, etc.) was noted. The specimens were mounted in a brass specimen holder using carbon tape to ensure electrical conductivity. Chemical analysis was performed using the EDX system attached to the microscope. The SEM was used with a working distance of 39 $\mathrm{mm}$ and an accelerating voltage of $20 \mathrm{kV}$. All SEM micrographs were taken with Polaroid no. 55 film.

\subsubsection{Transmission Electron Microscopy}

All alloys tested were analyzed by transmission electron microscopy (TEM) to determine the dislocation structure and the precipitates present. Chemical analysis of the precipitates was performed by an EDS system. TEM foils were taken from the fatigued regions of the specimens that were tested in air.

The foils were prepared by cutting off a thin section $(2 \mathrm{~mm})$ of the fracture surface on a slow speed diamond-blade cutoff wheel. The fracture surfaces were then carefully ground with 240 grit paper on a slow speed wheel as far as required to create a smooth surface and a total thickness of $0.15 \mathrm{~mm}$. Circular foils of $0.3 \mathrm{~mm}$ diameter were then produced by cutting with a slurry disk drill. The disks were then ground on both sides with 320 and 600 grit paper to a thickness of $90 \mu \mathrm{m}$. Electropolishing was then 
performed on the disks to perforation in a Ficshone jet-polisher with an electrolytic . solution consisting of $20 \%$ nitric acid in methanol. The parameters for jet-polishing were: $18 \mathrm{~mA},-30^{\circ} \mathrm{C}$ temperature, and 10 minuets of polishing time.

The TEM work was carried out on a Phillips CM-12 120 kV TEM. All TEM photographs were taken using Kodak Ectar high density electron microscope film.

\section{RESULTS}

\subsection{Grain Structure}

The 1 hour $700^{\circ} \mathrm{C}$ anneal resulted in a partially recrystallized structure for all the $\mathrm{Zr}$-containing alloys. The grain structure is left partially recrystallized as it has been found by researchers at ORNL to result in the highest ductility (5). Figure 3.1(a) shows the as-received $0.5 \% \mathrm{ZrC}$ while Fig. 3.1(b) shows the B2 ordered $0.5 \% \mathrm{ZrC}$. Figs. 3.2 (a) and 3.2(b) show the as received and B2 ordered $0.5 \% \mathrm{Zr}$ while Figs. 3.3(a) and 3.3(b) show the as received and $\mathrm{B} 2$ ordered $1 \% \mathrm{ZrC}$. Round precipitates were found in all $\mathrm{Zr}$ containing alloys as seen in Fig. 3.4a. Electron Dispersive X-Ray analysis (EDX) was performed in the Joel 840 SEM on the precipitates and they were found to be $\mathrm{Zr}$-rich (Fig. 3.4b). They were found to be non-homogeneously scattered throughout the material.

In the case of the ternary alloy the $700^{\circ} \mathrm{C}$ anneal resulted in near fully recrystallized structure with a grain size of $180 \mu \mathrm{m}$. The ternary grain structure is shown in Figs. 3.5(a) as received and (b) B2 ordered. Notice that the ternary alloy does not have the strong directional aspect to the structure as does the $\mathrm{Zr}$-containing alloys.

\section{$\underline{3.2 \text { Tensile Experiments }}$}

Tensile data for the iron aluminides examined are listed in Table 2. Alloy $0.5 \% \mathrm{ZrC}$ had the highest ductility and UTS of all alloys tested. Oxygen provided the 


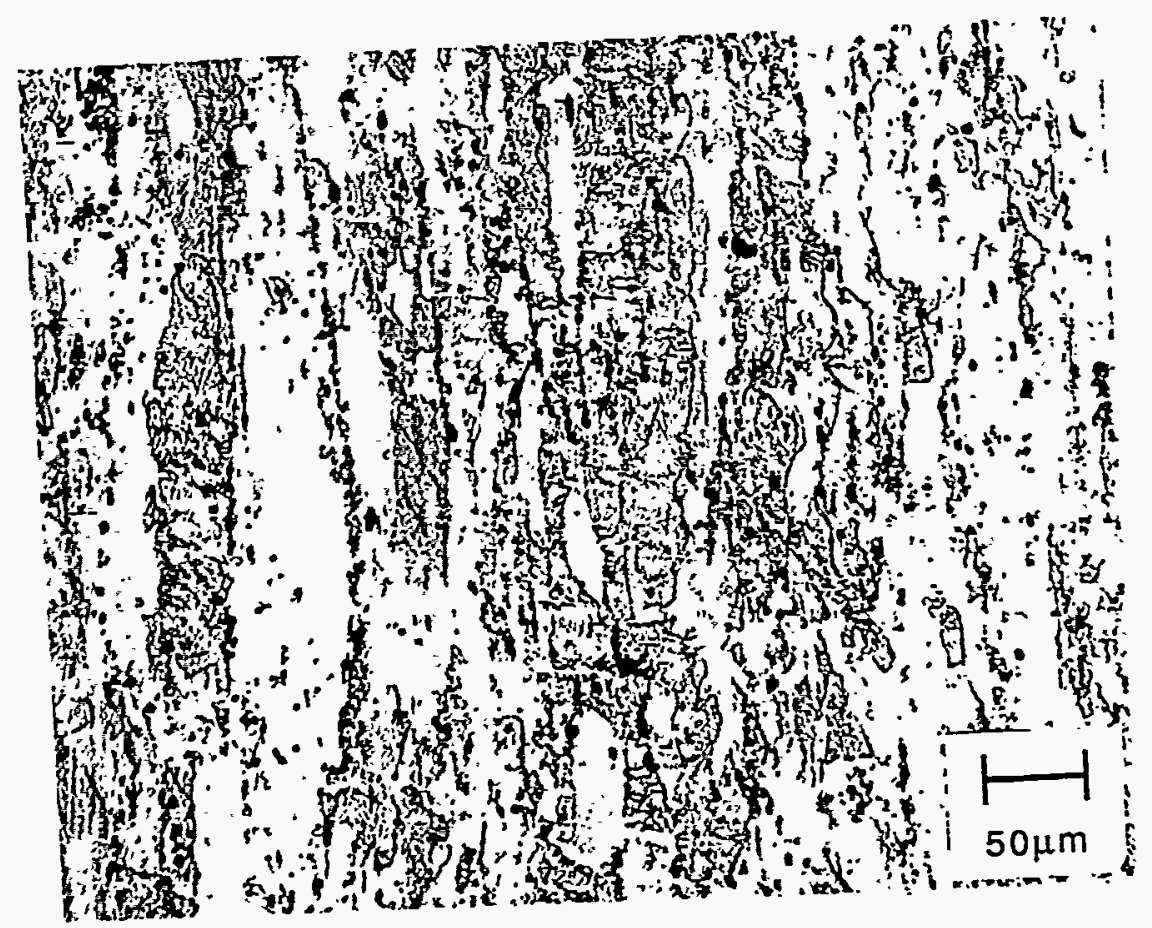

(a)

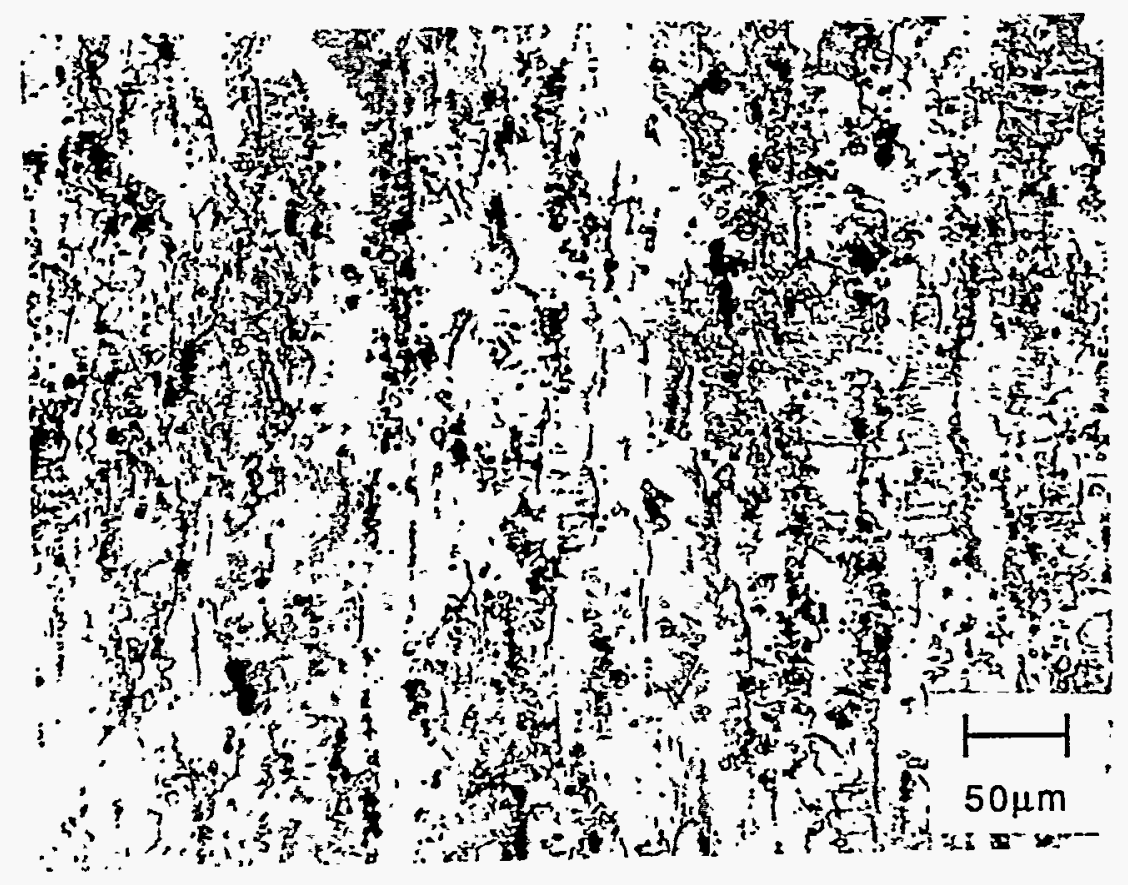

(b)

Fig. 3.1. Grain structure of the $0.5 \% \mathrm{ZrC}$ alloy in the as received structure (a) and B2 ordered (b). 


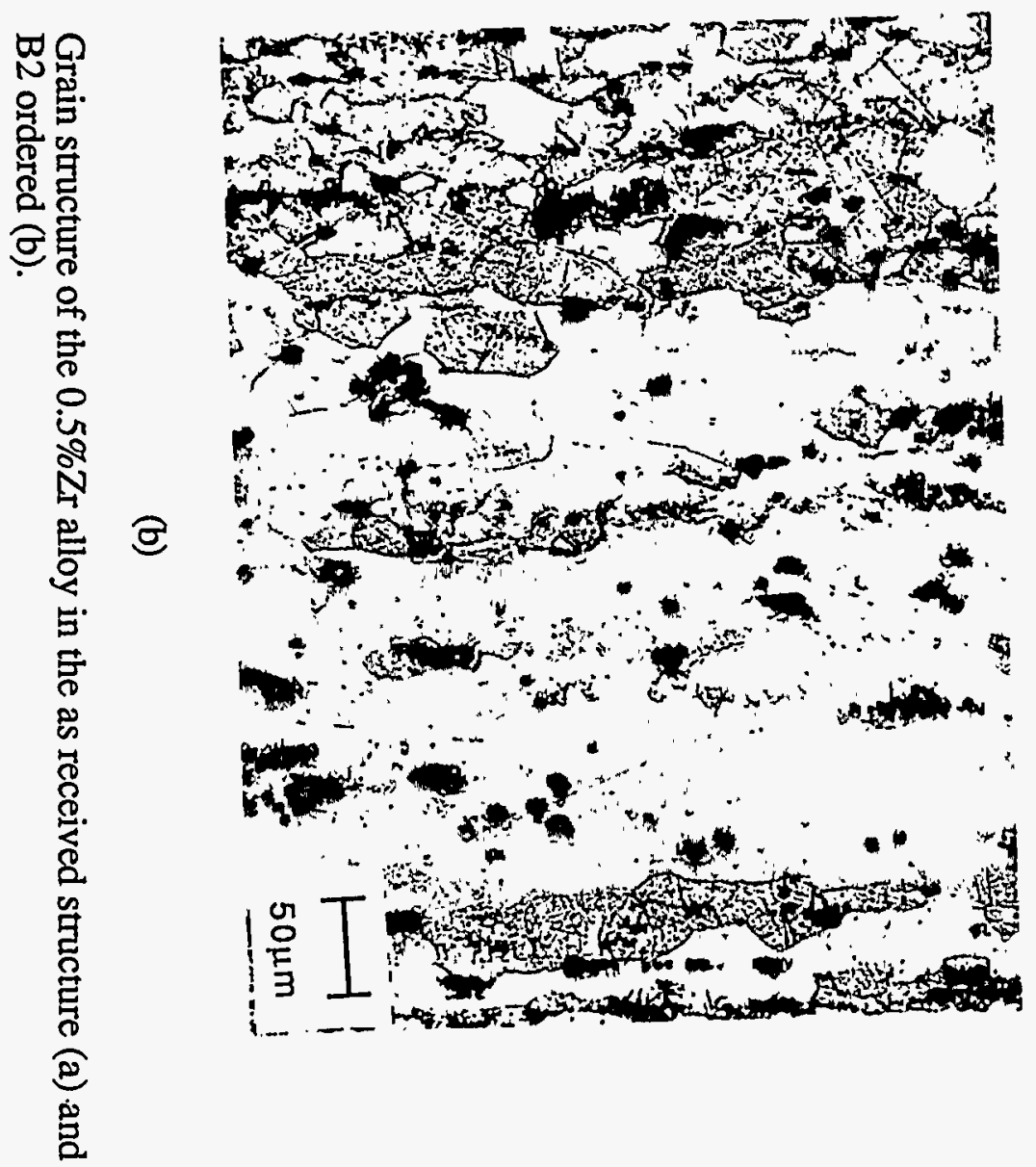

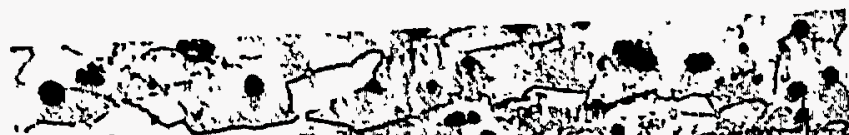

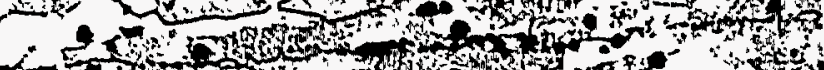
-7 us ofy

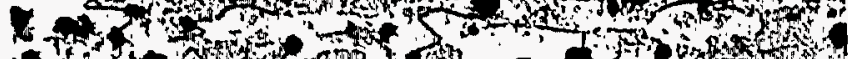

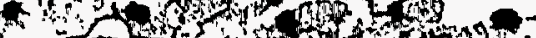

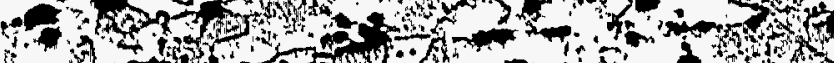

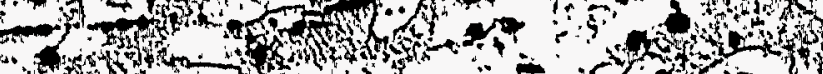

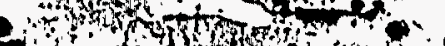

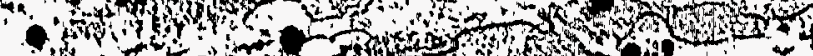

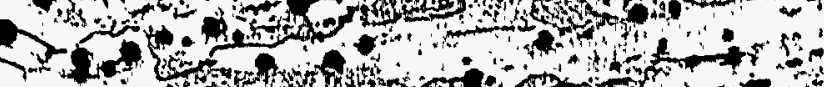

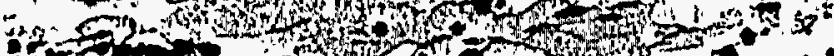
58 a 117.

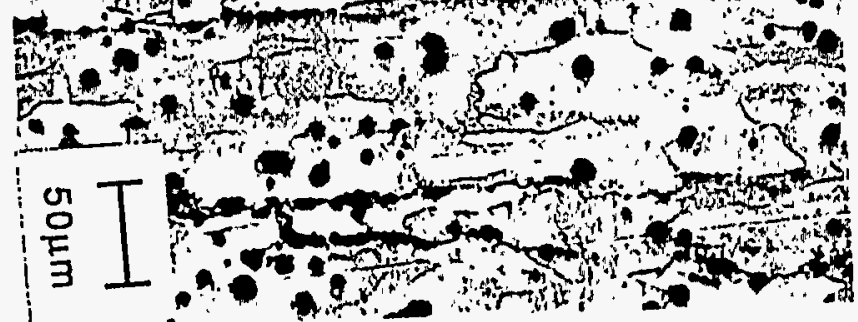




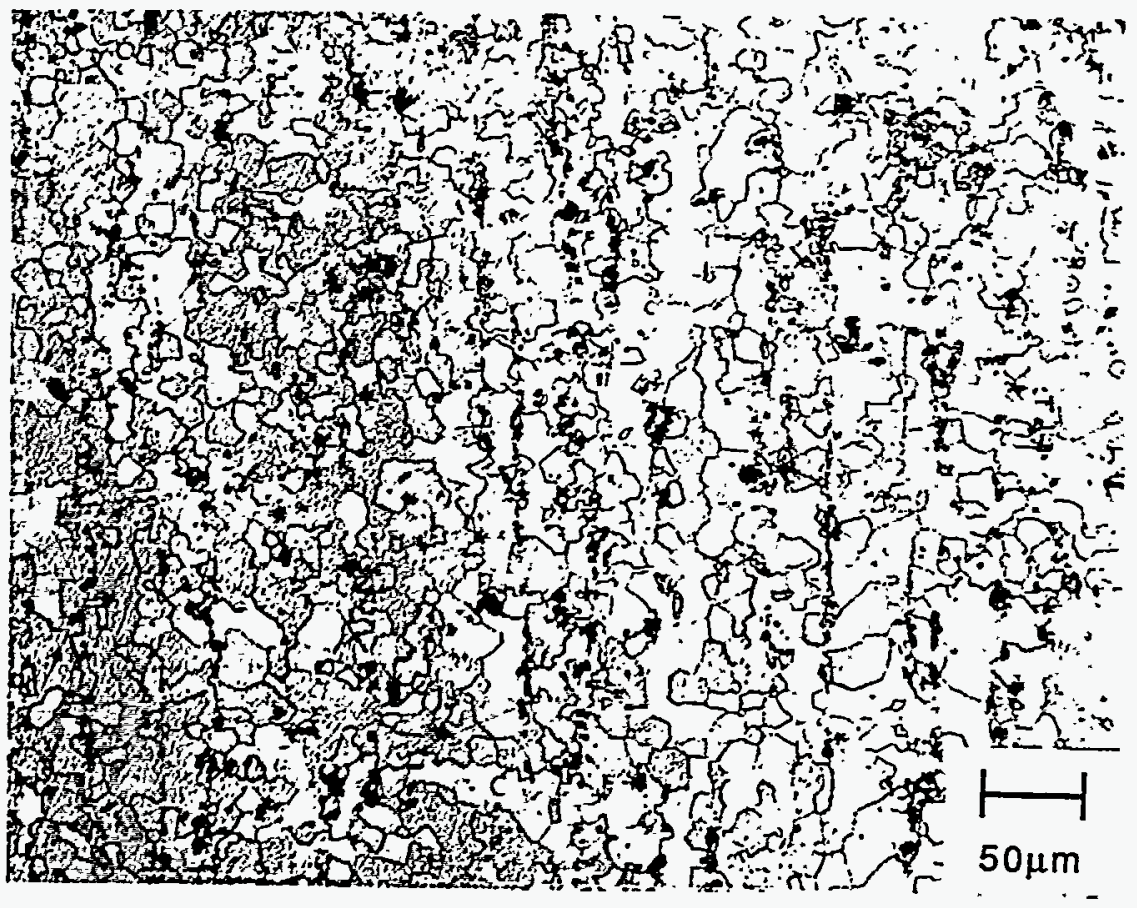

(a)

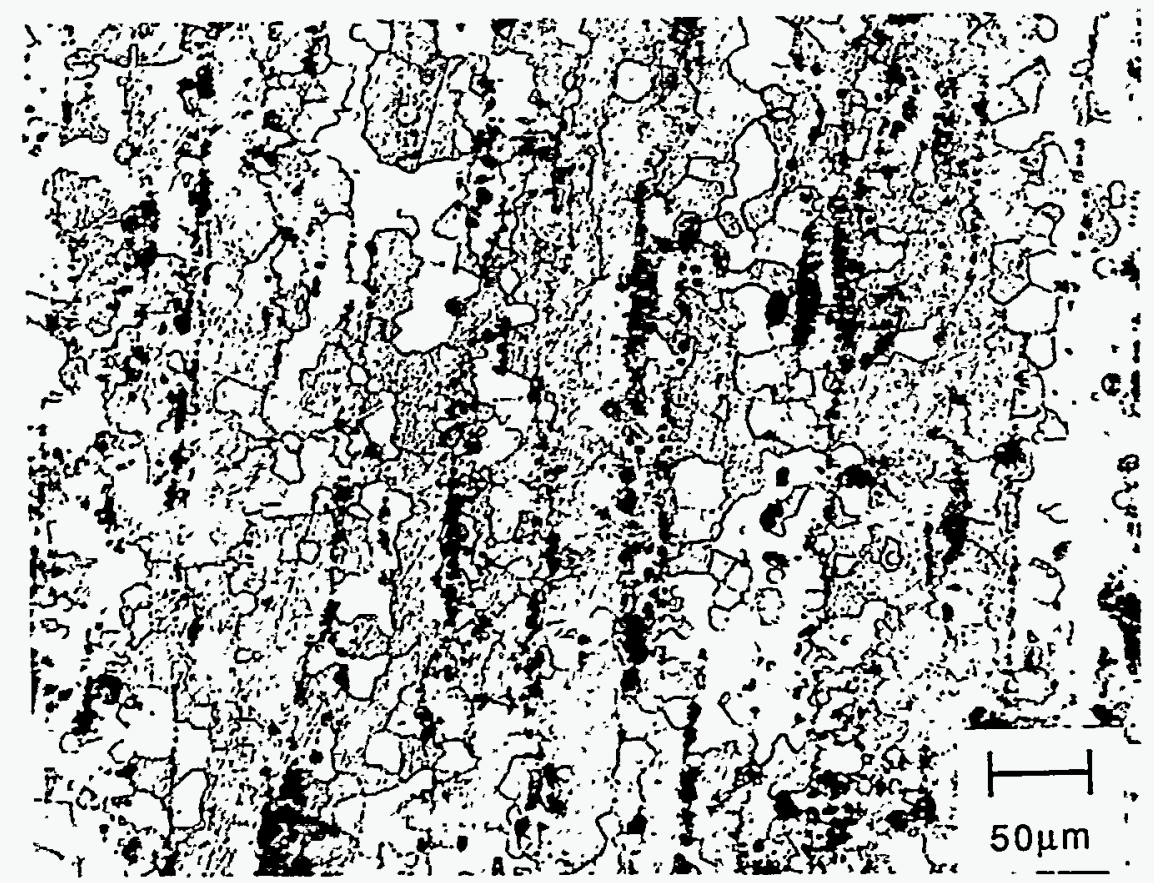

(b)

Fig. 3.3. Grain structure of the $1 \% \mathrm{ZrC}$ alloy in the as received structure (a) and B2 ordered (b). 


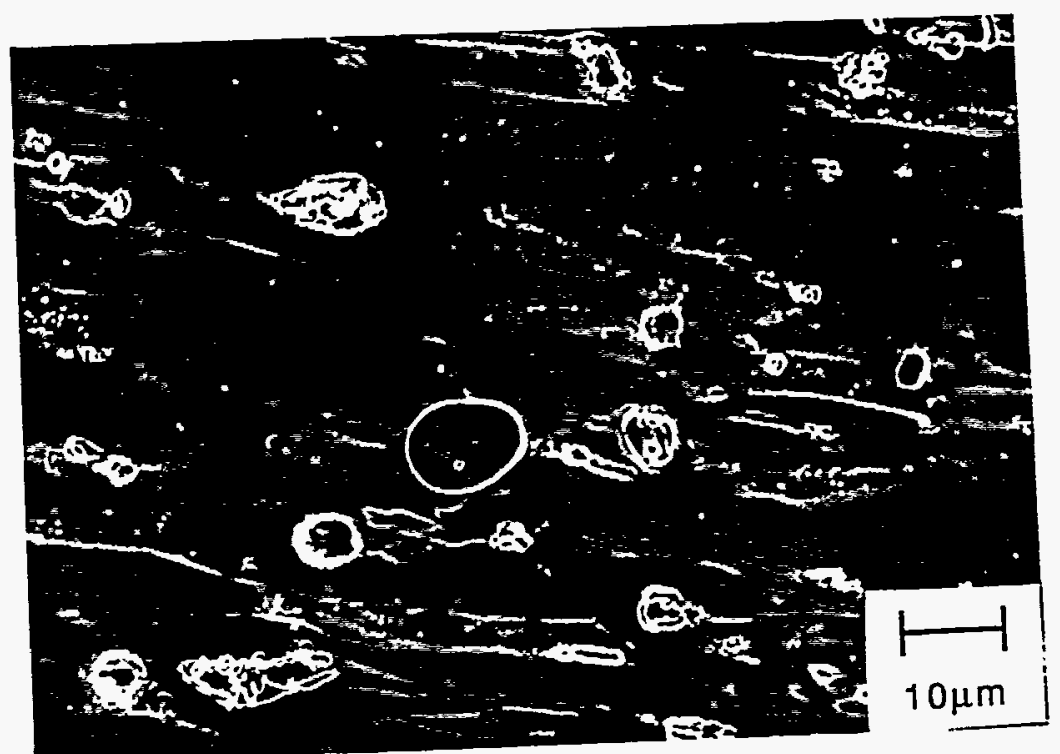

(a)

PPI MATERIRLS ENGINEERING Cursor: $0.000 \mathrm{keV}=0$

THU 33-NOV -40

$21: 49$

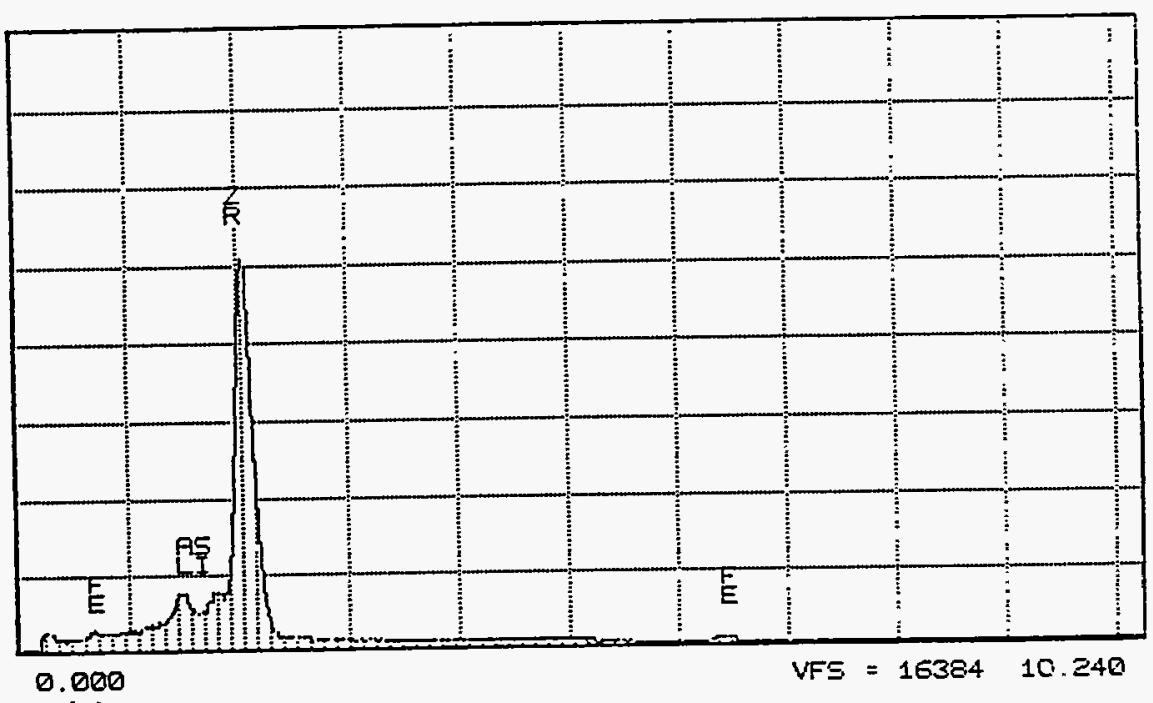

(b)

Fig. 3.4. Round precipitate found in $\mathrm{Zr}$-containing alloys (a) EDX spectrum showing the composition of the precipitate 


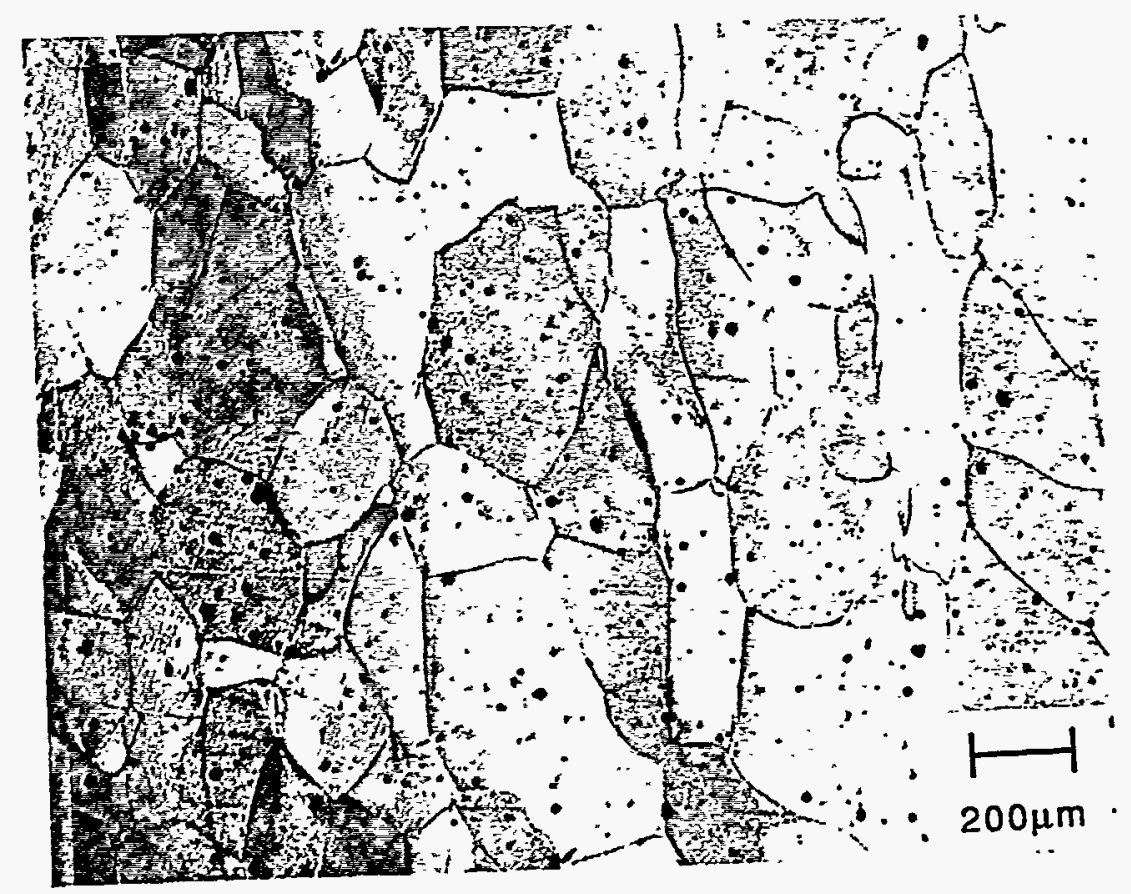

(a)

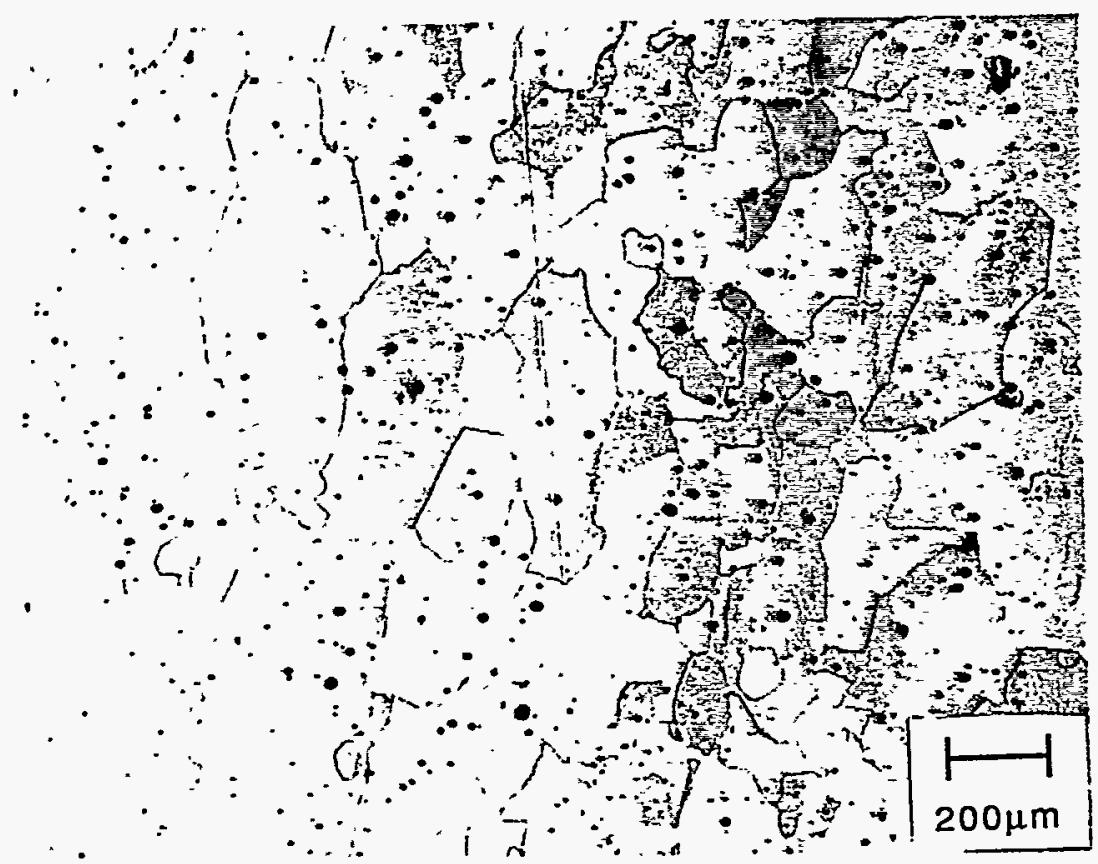

(b)

Fig. 3.5. Grain structure of the Ternary alloy in the as received structure (a) and B2 ordered (b). 
highest ductility and UTS for the Ternary alloy while $0.5 \% \mathrm{ZrC}$ had the same values of ductility and UTS in air and oxygen. Increasing the amount of $\mathrm{Zr}$ to $1 \mathrm{a} \%$ resulted in a decrease of both the ductility and UTS, while the removal of C also decreased the ductility and UTS, but not as severely.

Figs. 3.6(a) - 3.6(d) show the fracture surfaces of all the alloys tested in air. Fractographic features were found to be insensitive to environment in both the ternary and the $0.5 \% \mathrm{ZrC}$ alloys. The fracture mode was observed to be mixed transgranular cleavage and intergranular fracture in the ternary alloy with a switch to transgranular cleavage and dimpled rupture in the $0.5 \% \mathrm{ZrC}$ and $0.5 \% \mathrm{Zr}$ alloys. The fracture mode reverted back to mixed transgranular cleavage and intergranular fracture in the $1 \% \mathrm{ZrC}$ alloy.

\subsection{Fatigue Crack Growth Experiments}

\subsubsection{Effect of Composition}

Fatigue crack growth curves are shown in Figs. 3.7 - 3.10 for the iron aluminides studied. Table 3 lists the threshold and critical stress intensities, as well as the stress intensity necessary to produce a crack growth rate of $10^{-7} \mathrm{~m} /$ cycle. The slope in the Paris regime is not reported since a linear region in the $\mathrm{da} / \mathrm{dN}$ vs. $\Delta \mathrm{K}$ curves could not always be defined.

TABLE 2.

Tensile Properties of B2 Iron Aluminides

\begin{tabular}{|c|c|c|c|c|c|c|c|c|c|}
\hline Alloy & $\begin{array}{l}\mathrm{YS} \\
(\mathrm{MPa})\end{array}$ & $\begin{array}{l}\text { Air } \\
\text { UTS } \\
\text { (MPa) }\end{array}$ & $\begin{array}{l}\text { Ductility } \\
(\%)\end{array}$ & $\begin{array}{l}\text { YS } \\
(\mathrm{MPa}) \\
\end{array}$ & $\begin{array}{l}\mathrm{O}_{2} \\
\mathrm{UTS} \\
(\mathrm{MPa})\end{array}$ & $\begin{array}{l}\text { Ductility } \\
\text { (\%) }\end{array}$ & $\begin{array}{l}\mathrm{YS} \\
(\mathrm{MPa})\end{array}$ & $\begin{array}{l}\mathrm{H}_{2} \\
\mathrm{UTS} \\
(\mathrm{MPa})\end{array}$ & $\begin{array}{l}\text { Ductility } \\
\text { (\%) }\end{array}$ \\
\hline Tern & 500 & 980 & 10.2 & 510 & 1180 & 12.8 & 500 & 740 & 4.2 \\
\hline $0.5 \% \mathrm{ZrC}$ & 690 & 1460 & 13.8 & 680 & 1460 & 13.1 & 680 & 1200 & 6.1 \\
\hline $0.5 \% \mathrm{Zr} *$ & 670 & 1000 & 8.2 & - & - & - & - & - & - \\
\hline $1 \% \mathrm{ZrC} *$ & 510 & 880 & 5.3 & - & - & - & - & - & - \\
\hline
\end{tabular}

* Average of three tests 


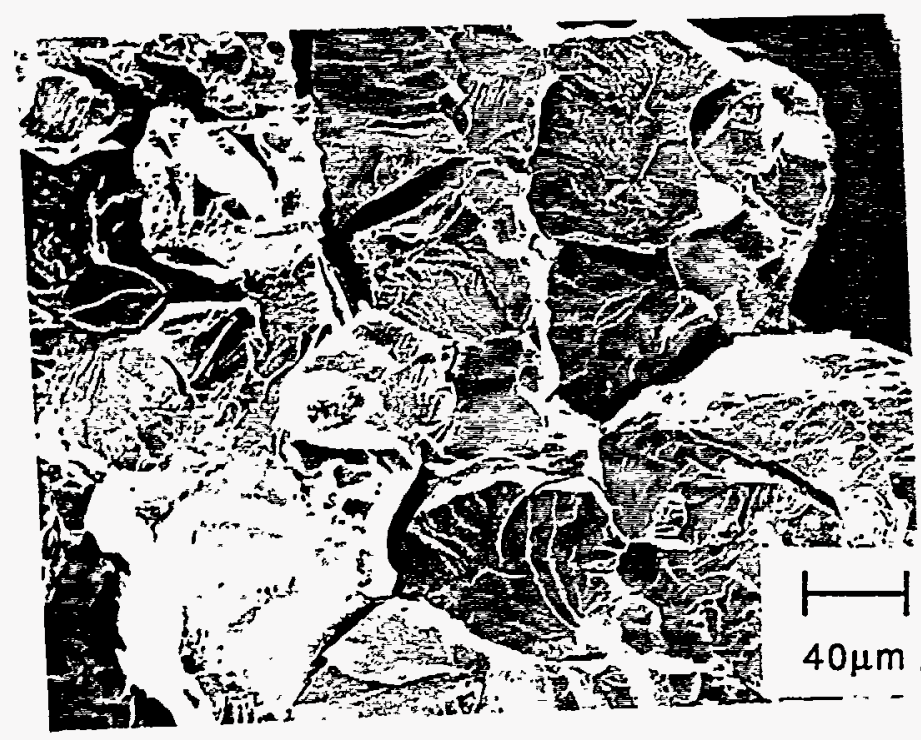

(a)

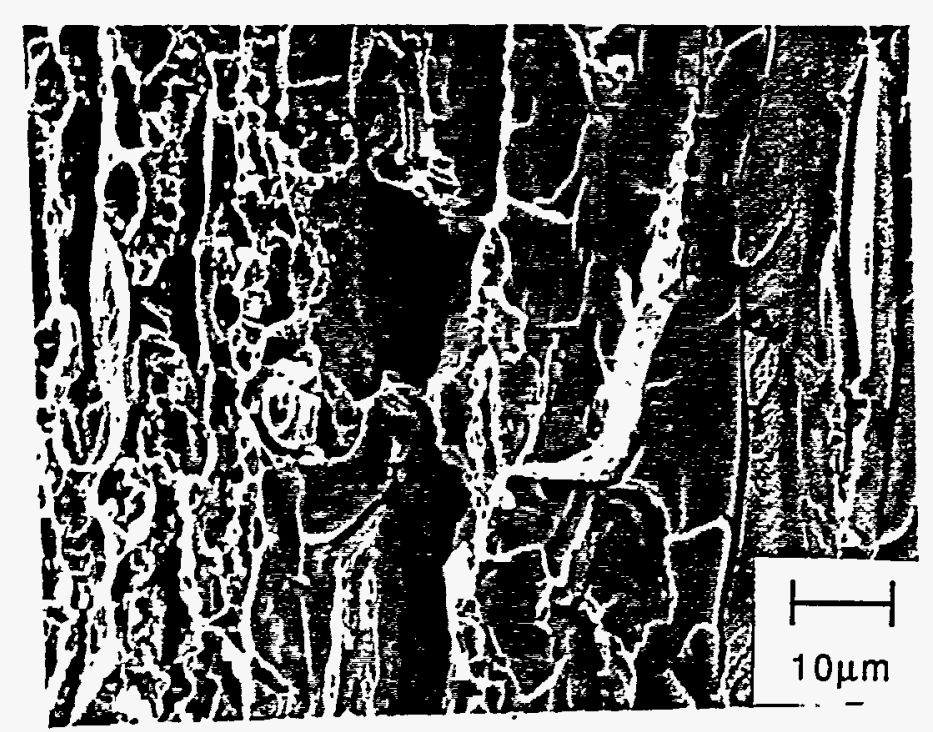

(c)

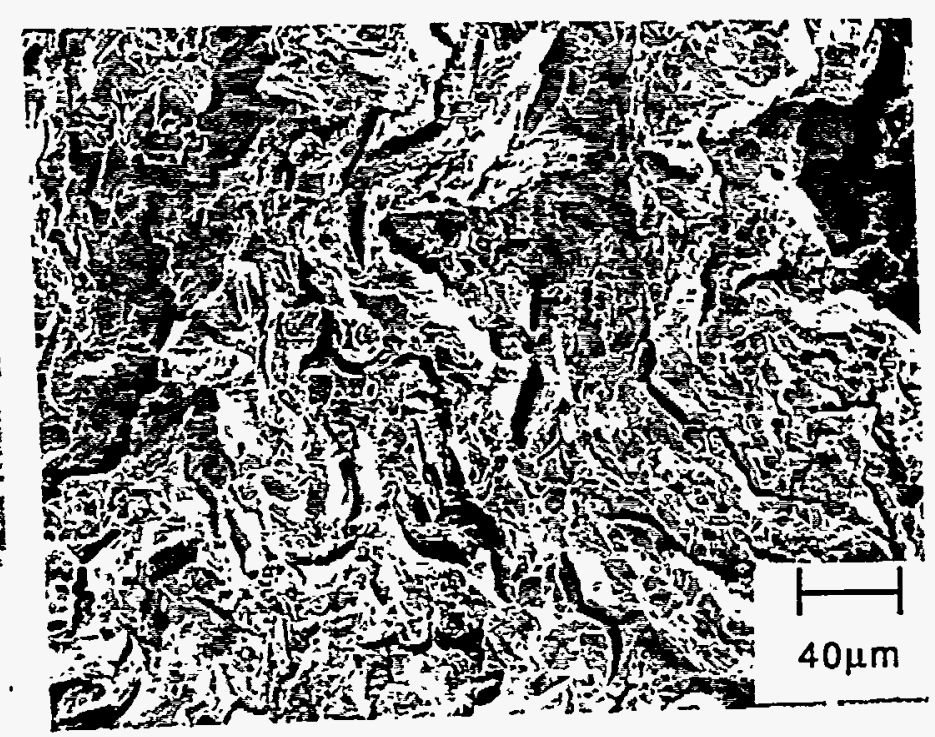

(b)

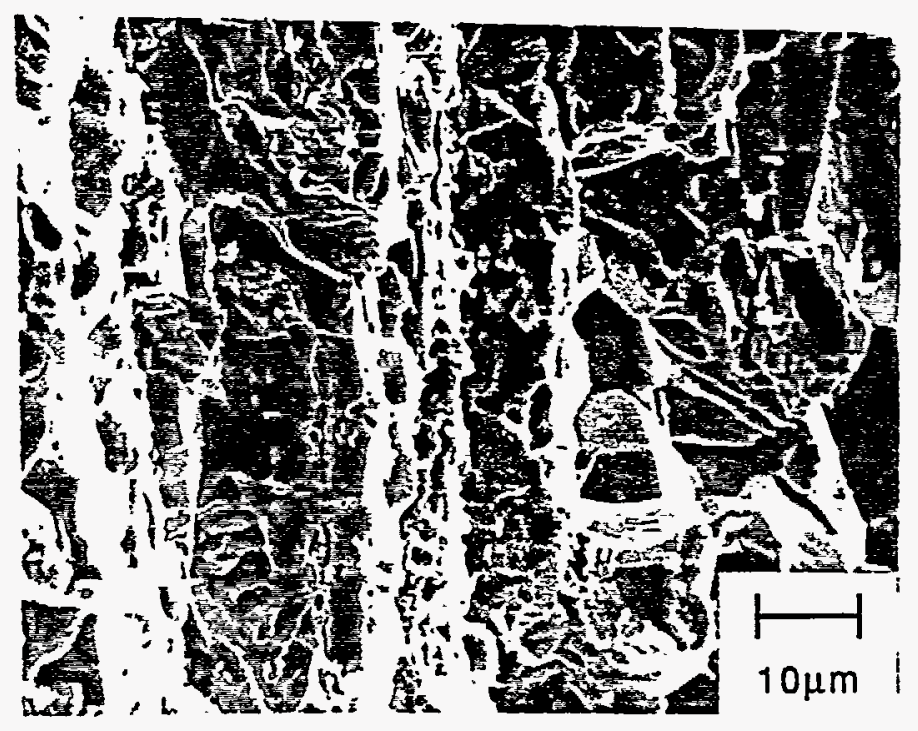

(d)

Fig. 3.6. Fracture Surfaces of the (a) Ternary Alloy, (b) $0.5 \% \mathrm{ZrC}$ Alloy, (c) $0.5 \% \mathrm{Zr}$ Alloy and (d) $1 \% \mathrm{ZrC}$ Alloy Tested in Tension at $25^{\circ} \mathrm{C}$ in Air 
TABLE 3.

FCG Data for the B2 Iron Aluminides

\begin{tabular}{|c|c|c|c|c|c|}
\hline Alloy & Environment & $\begin{array}{l}\mathrm{KK}\left(10^{-7}\right) \\
\left(\mathrm{MPa} \mathrm{J}_{\mathrm{m}}\right)\end{array}$ & $\begin{array}{l}\Delta \bar{K}_{\mathrm{TH}} \\
\left(\mathrm{MPa} \vee_{\mathrm{m}}\right)\end{array}$ & $\begin{array}{l}\Delta \mathrm{K}_{\mathrm{C}} \\
\left(\mathrm{MPa} \mathrm{V}_{\mathrm{m}}\right)\end{array}$ & $\begin{array}{l}\text { Failure } \\
\text { Mode }\end{array}$ \\
\hline Ternary & Air (30\% rH) & 20.3 & 16.9 & 26.4 & TG, IG \\
\hline Ternary & $\mathrm{O}_{2}$ & 38.4 & 24.2 & 42.4 & TG, IG \\
\hline Ternary & Vacuum & 32.6 & 29.2 & 39.1 & TG, IG \\
\hline Ternary & $\mathrm{H}_{2}$ & 15.1 & 14.2 & 19.9 & $\mathrm{TG}, \mathrm{IG}$ \\
\hline $0.5 \% \mathrm{ZrC}$ & $\operatorname{Air}(21 \% \mathrm{rH})$ & 29.0 & 18.0 & 59.4 & TG tearing \\
\hline $0.5 \% \mathrm{ZrC}$ & $\mathrm{Air}(48 \% \mathrm{rH})$ & 27.1 & 18.0 & 47.4 & TG tearing \\
\hline $0.5 \% \mathrm{ZrC}$ & $\operatorname{Air}(81 \% \mathrm{rH})$ & 24.3 & 17.9 & 37.2 & TG tearing \\
\hline $0.5 \% \mathrm{ZrC}$ & $\mathrm{O}_{2}$ & 42.3 & 18.6 & 68.7 & TG tearing \\
\hline $0.5 \% \mathrm{ZrC}$ & Vacuum & 29.0 & 23.2 & 38.0 & TG tearing \\
\hline $0.5 \% \mathrm{ZrC}$ & $\mathrm{H}_{2}$ & 21.1 & 19.8 & 42.8 & TG tearing \\
\hline $0.5 \% \mathrm{Zr}$ & $\mathrm{Air}(21 \% \dot{\mathrm{r} H})$ & 28.1 & 18.7 & 39.0 & TG, IG \\
\hline $0.5 \% \mathrm{Zr}$ & $\operatorname{Air}(48 \% \mathrm{rH})$ & 25.2 & 18.9 & 34.3 & $\mathrm{TG}, \mathrm{IG}$ \\
\hline $0.5 \% \mathrm{Zr}$ & $\operatorname{Air}(81 \% \mathrm{rH})$ & 23.9 & 19.2 & 32.2 & TG, IG \\
\hline $0.5 \% \mathrm{Zr}$ & $\mathrm{O}_{2}$ & 43.3 & 20.0 & 48.9 & TG, IG \\
\hline $0.5 \% \mathrm{Zr}$ & Vacuum & 32.6 & 32.5 & 46.1 & TG, IG \\
\hline $0.5 \% \mathrm{Zr}$ & $\mathrm{H}_{2}$ & 21.2 & 20.5 & 38.9 & TG, IG \\
\hline $1 \% \mathrm{ZrC}$ & Air $(21 \% \mathrm{rH})$ & 22.8 & 16.2 & 27.6 & $\begin{array}{l}\text { TG, tearing, } \\
\text { some IG }\end{array}$ \\
\hline $1 \% \mathrm{ZrC}$ & Air $(48 \% \mathrm{rH})$ & 21.2 & 16.7 & 27.1 & $\begin{array}{l}\text { TG, tearing, } \\
\text { some IG }\end{array}$ \\
\hline $1 \% \mathrm{ZrC}$ & $\operatorname{Air}(81 \% \mathrm{rH})$ & 20.2 & 17.1 & 23.6 & $\begin{array}{l}\text { TG, tearing, } \\
\text { some IG }\end{array}$ \\
\hline $1 \% \mathrm{ZrC}$ & $\mathrm{O}_{2}$ & 35.9 & 23.0 & 36.8 & TG, tearing \\
\hline $1 \% \mathrm{ZrC}$ & Vacuum & 30.4 & 26.9 & 35.1 & $\mathrm{TG}$, tearing \\
\hline $1 \% \mathrm{ZrC}$ & $\mathrm{H}_{2}$ & 21.2 & 20.5 & 38.9 & $\begin{array}{l}\text { TG, tearing, } \\
\text { some IG }\end{array}$ \\
\hline
\end{tabular}




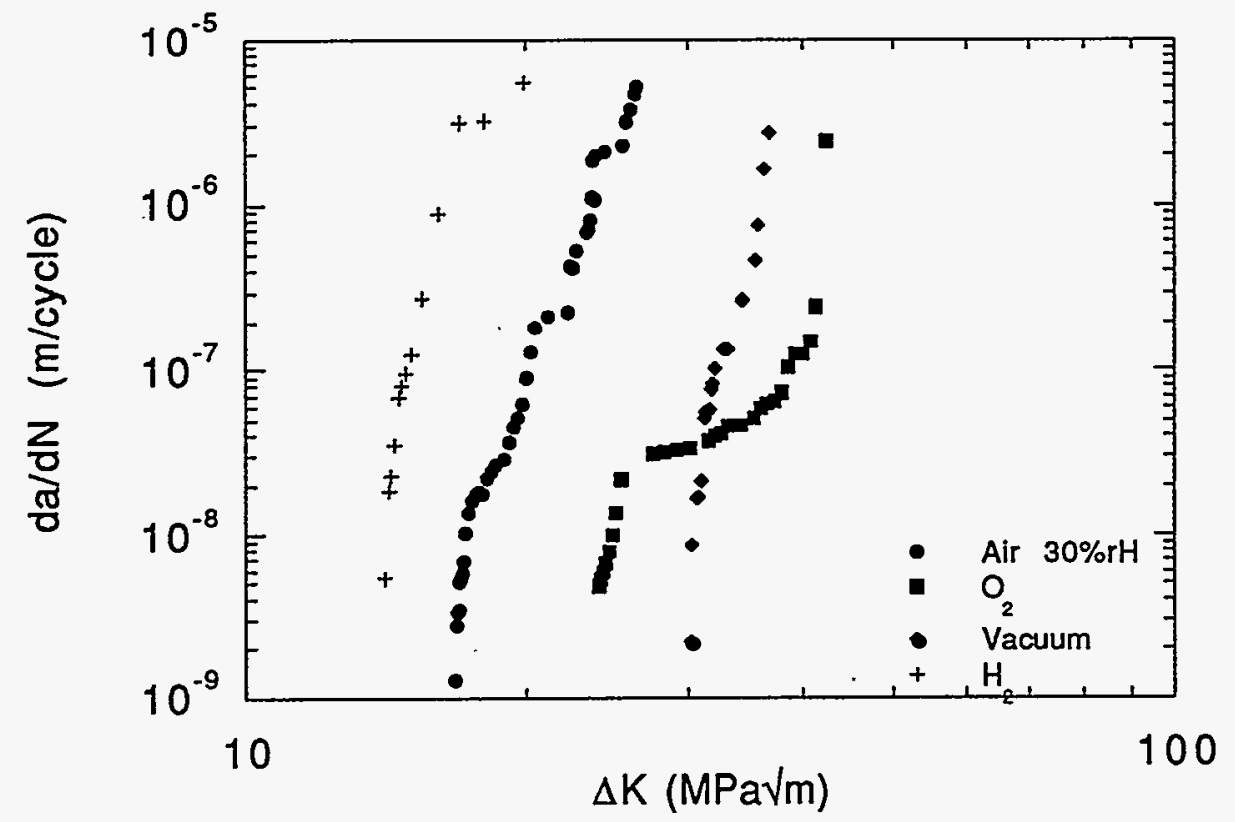

Fig. 3.7. Fatigue Crack Growth Curves for the Ternary Alloy at $25^{\circ} \mathrm{C}$.

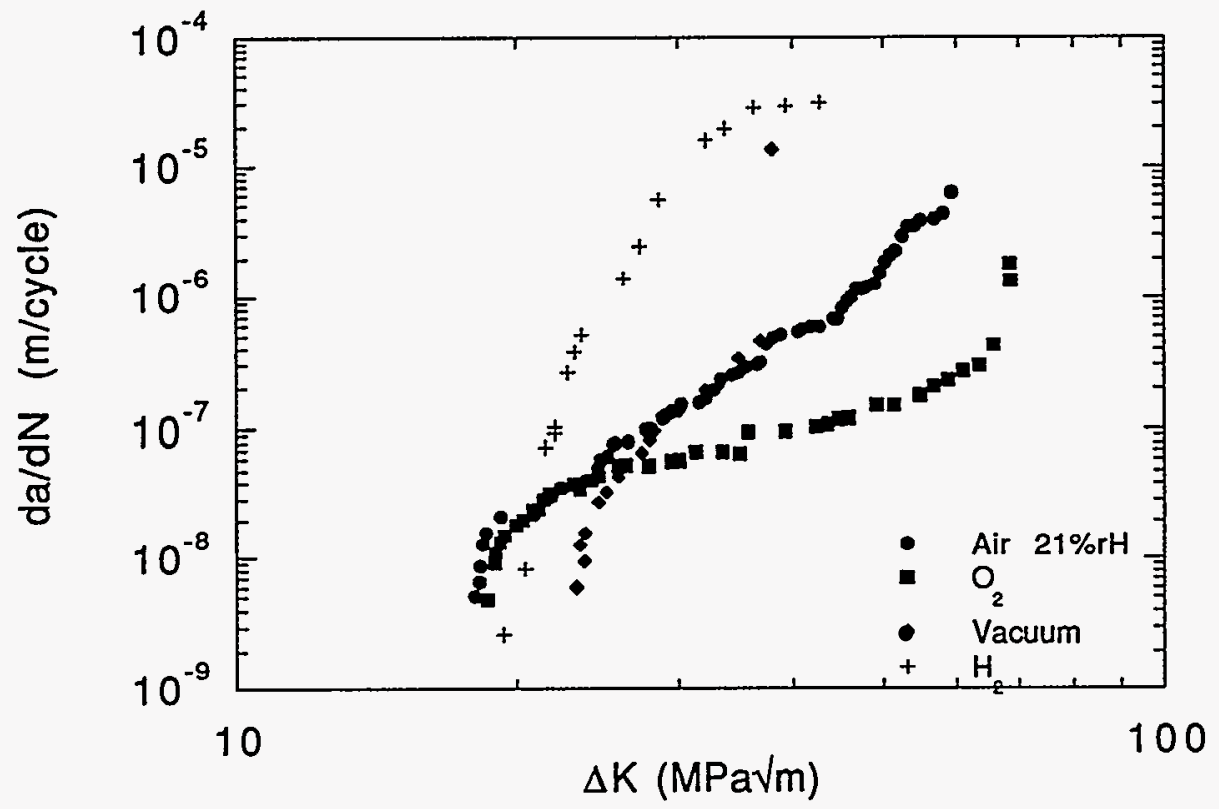

Fig. 3.8. Fatigue Crack Growth Curves for the $0.5 \% \mathrm{ZrC}$ alloy at $25^{\circ} \mathrm{C}$. 


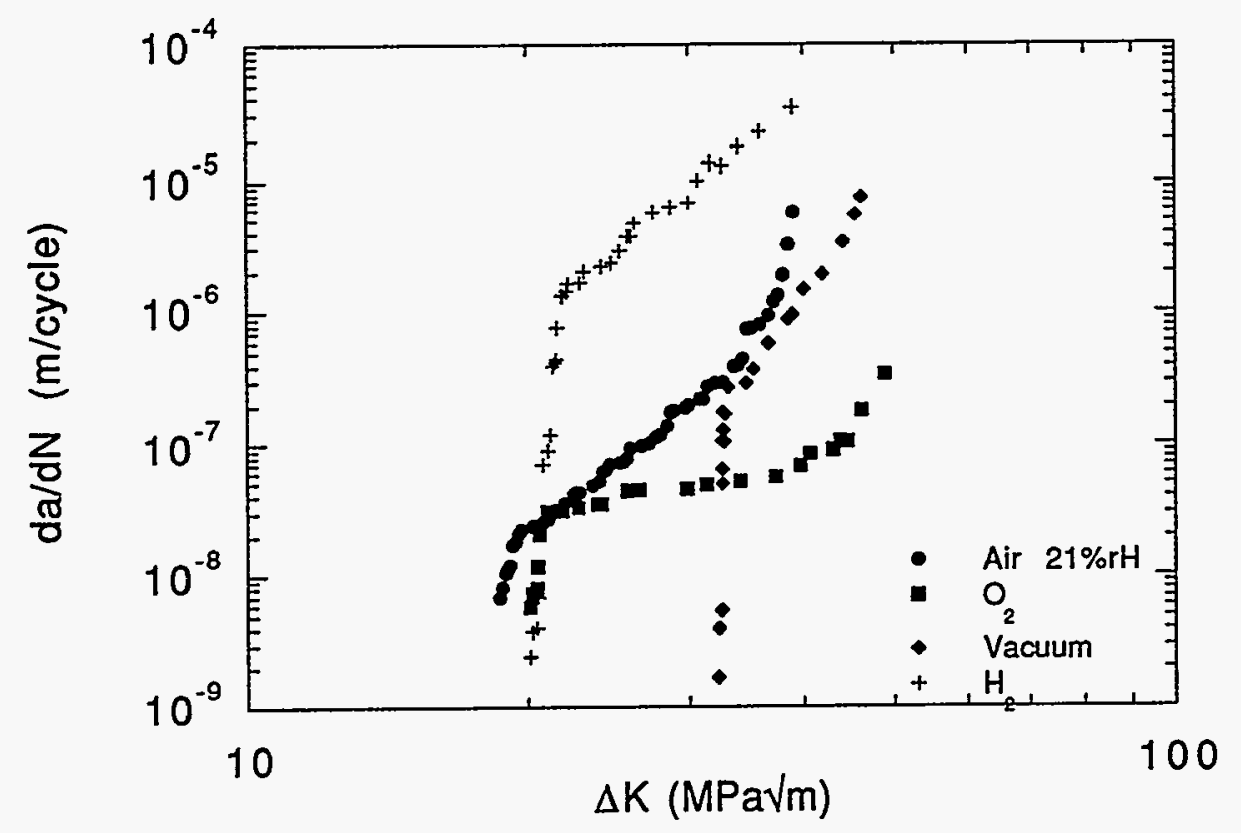

Fig. 3.9. Fatigue Crack Growth Curves for the $0.5 \% \mathrm{Zr}$ Alloy at $25^{\circ} \mathrm{C}$.

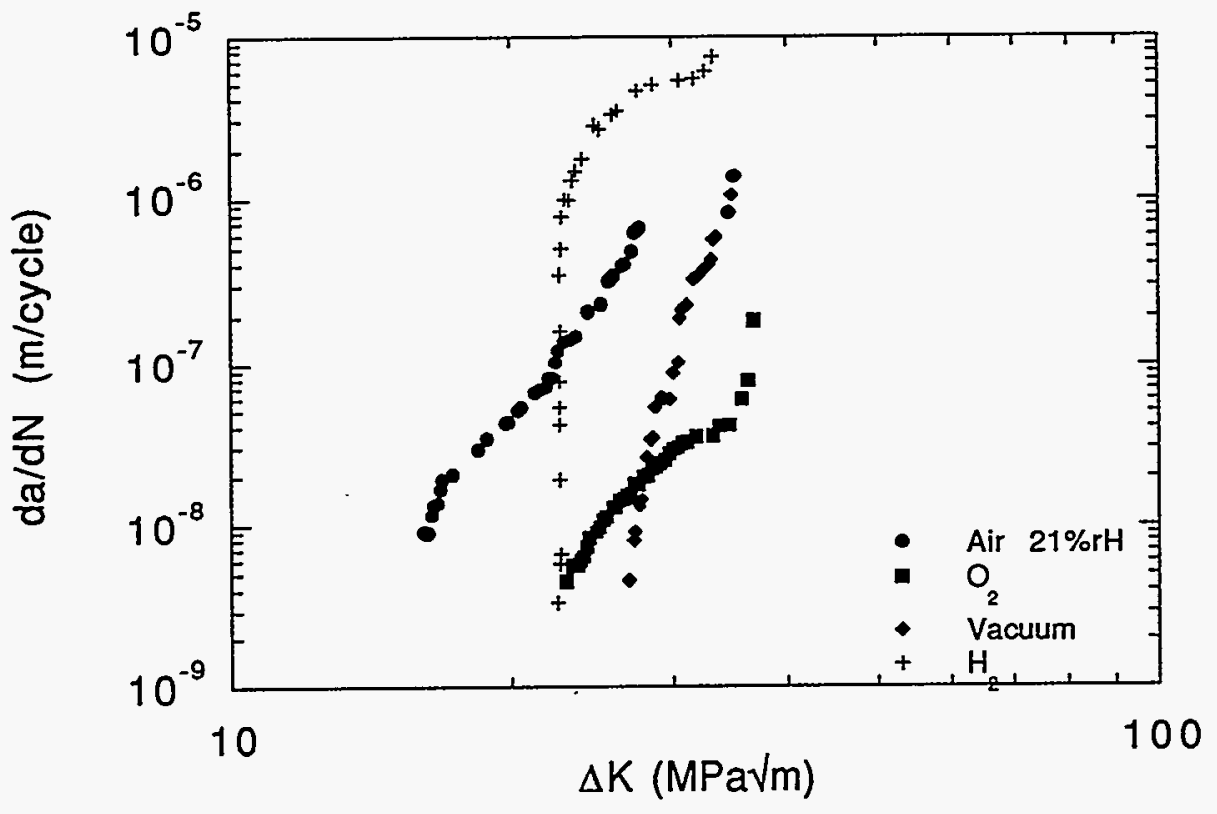

Fig. 3.10. Fatigue Crack Growth Curves for the $1 \% \mathrm{ZrC}$ Alloy at $25^{\circ} \mathrm{C}$. 
In all alloys tested oxygen provides the lowest crack growth rates. The $0.5 \% \mathrm{ZrC}$ alloy has the highest critical stress intensity values in all environments, except vacuum, of the alloys studied. The addition of carbon to the $0.5 \% \mathrm{Zr}$ alloy does not affect the crack growth rates but significantly increases the fracture toughness. The increase in $\mathrm{Zr}$ content to $1 \mathrm{a} \%$ is detrimental to the crack growth resistance while increasing the threshold stress intensities in all environments except air. In all $\mathrm{Zr}$-containing alloys the threshold stress intensity when tested in hydrogen gas was found to be higher than in air.

Figs. 3.11(a) - 3.11(d) show the fracture surfaces of the fatigued specimens. The fracture surfaces were found to be insensitive to environment for all alloys except for $1 \% \mathrm{ZrC}$. The ternary alloy exhibited mixed transgranular cleavage and intergranular fracture, while the fracture mode of the $0.5 \% \mathrm{ZrC}$ alloy was transgranular, by what appears to be a tearing mechanism. The $0.5 \% \mathrm{Zr}$ alloy failed by mostly transgranular tearing. The $1 \% \mathrm{ZrC}$ alloy failed by mixed transgranular tearing with some intergranular fracture in hydrogen bering environments, while it failed by transgranular tearing in inert environments

\subsubsection{Effect of Humidity}

The effect of constant humidity on the iron aluminides studied is shown in Figs. 3.12 - 3.14. Table 3 lists the threshold and critical stress intensities as well as the stress intensity necessary for a crack growth rate of $10^{-7} \mathrm{~m} /$ cycle.

In all alloys tested in controlled humidity the fatigue crack growth resistance decreased with increasing humidity. The alloy with $1 \mathrm{a} \% \mathrm{Zr}$ was the most resistant to humidity changes while the alloy with $0.5 \mathrm{a} \% \mathrm{Zr}$ and carbon was the least. In all alloys the change in humidity had little or no affect on $\Delta \mathrm{K}_{\mathrm{th}}$. The largest change was $5 \%$ for the $1 \% \mathrm{Zr}$ alloy. The fracture mode was also found to be unchanged with humidity for each alloy tested. 


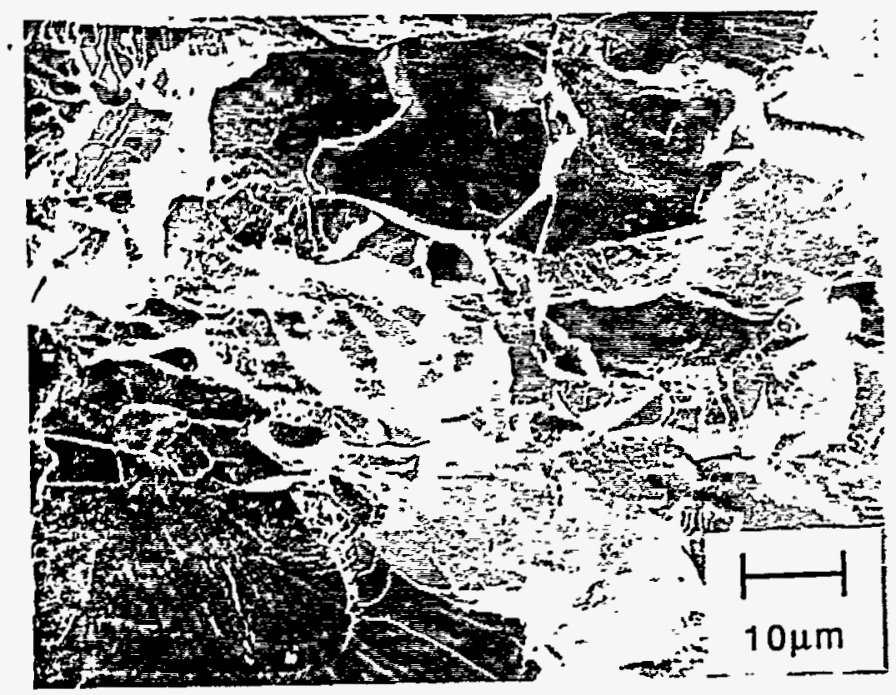

(a)

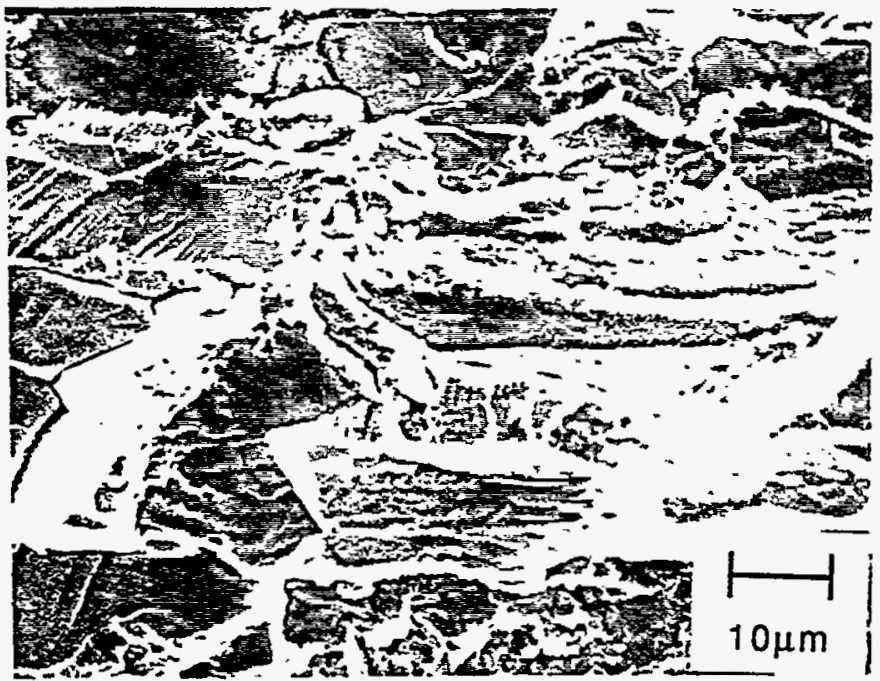

(b)

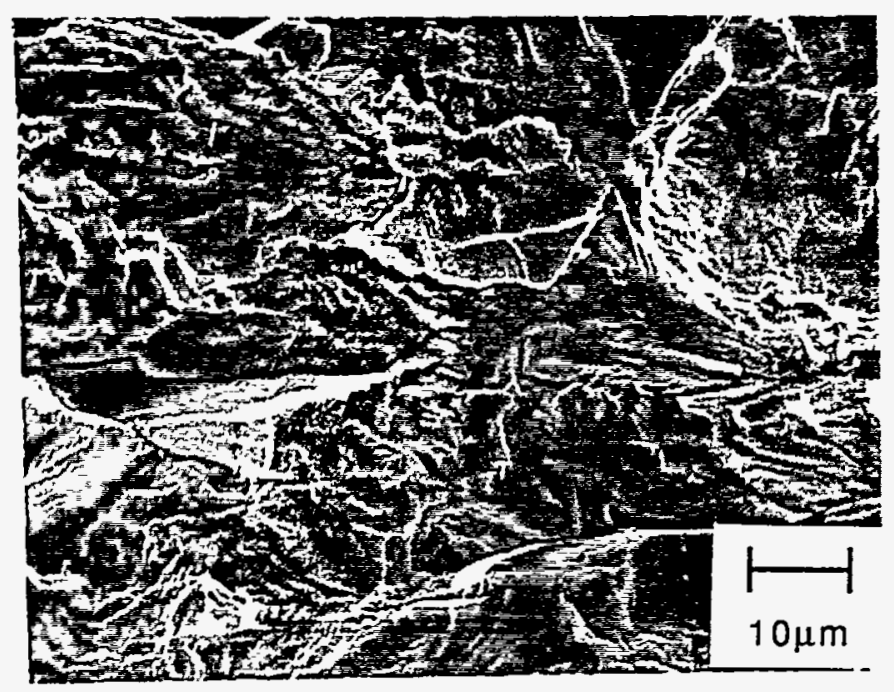

(c)

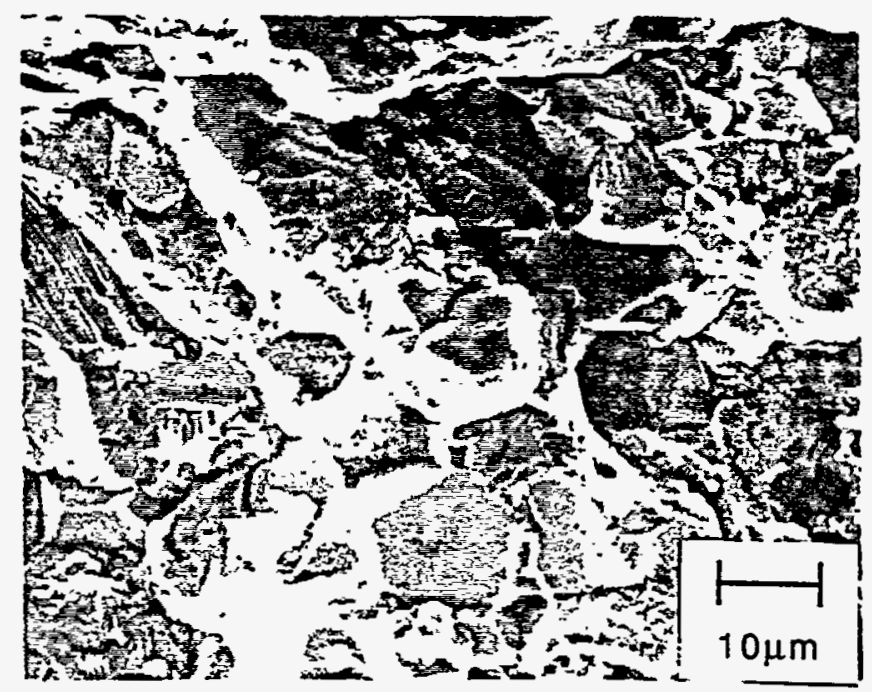

(d)

Fig. 3.11. Fracture Surfaces of (a) Ternary Alloy, (b) $0.5 \% \mathrm{ZrC}$ Alloy, (c) $0.5 \% \mathrm{Zr}$ Alloy and (d) $1 \% \mathrm{ZrC}$ Alloy Fatigued at $25^{\circ} \mathrm{C}$ in Air 


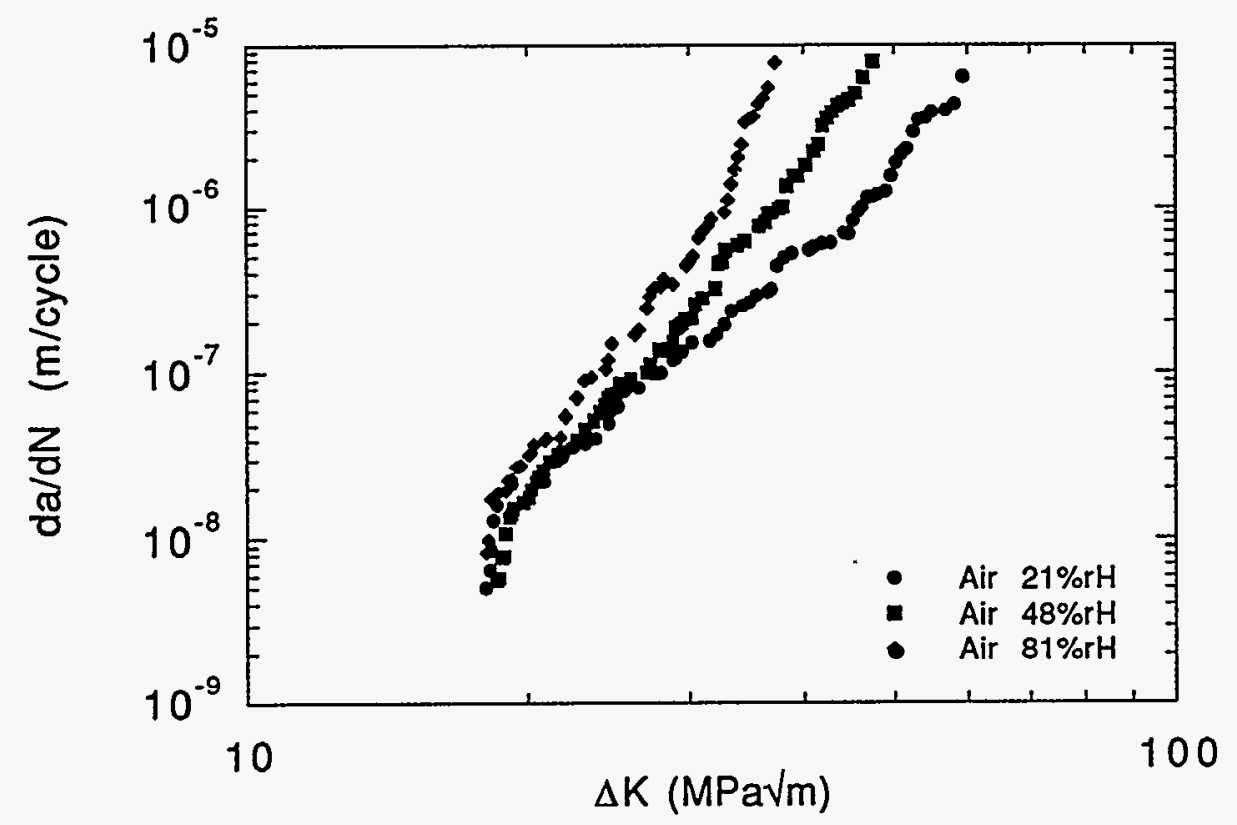

Fig. 3.12. Fatigue Crack Growth Curves for the $0.5 \% \mathrm{ZrC}$ Alloy at $25^{\circ} \mathrm{C}$.

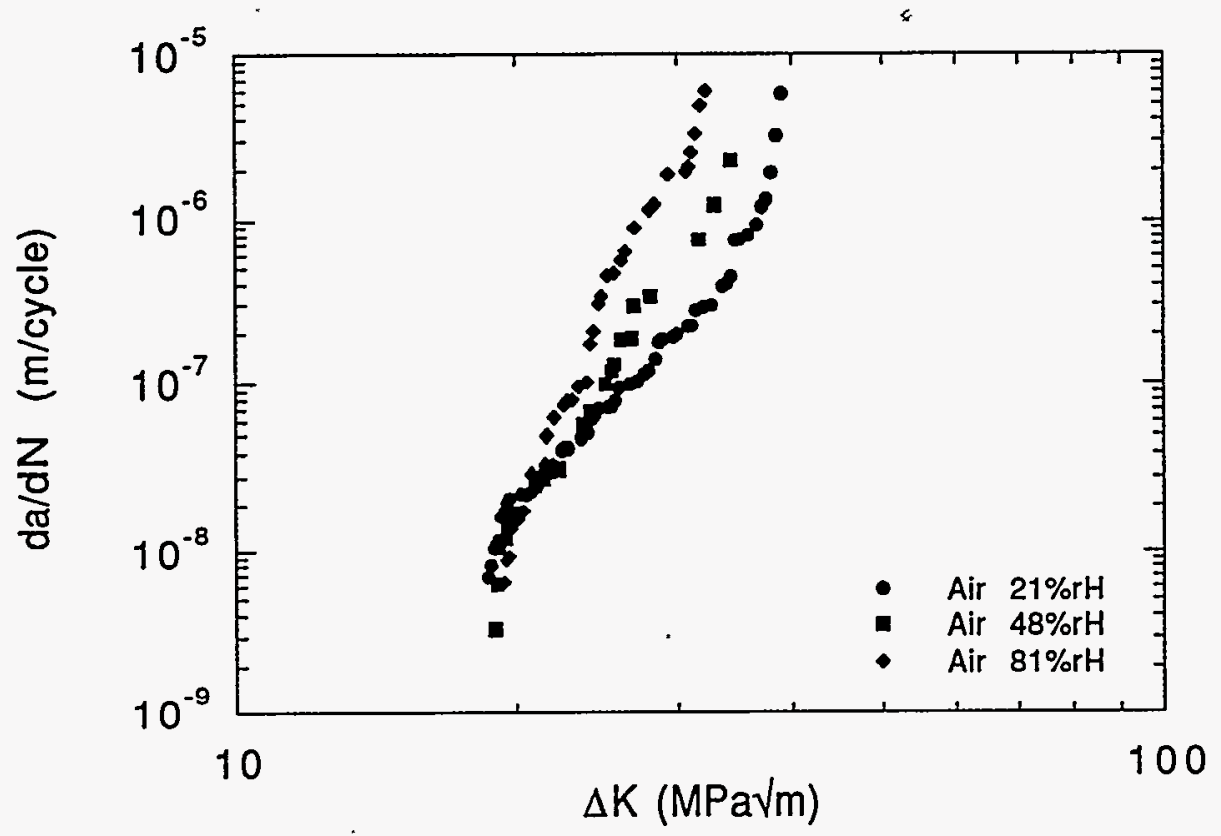

Fig. 3.13. Fatigue Crack Growth Curves for the $0.5 \% \mathrm{Zr}$ Alloy at $25^{\circ} \mathrm{C}$. 


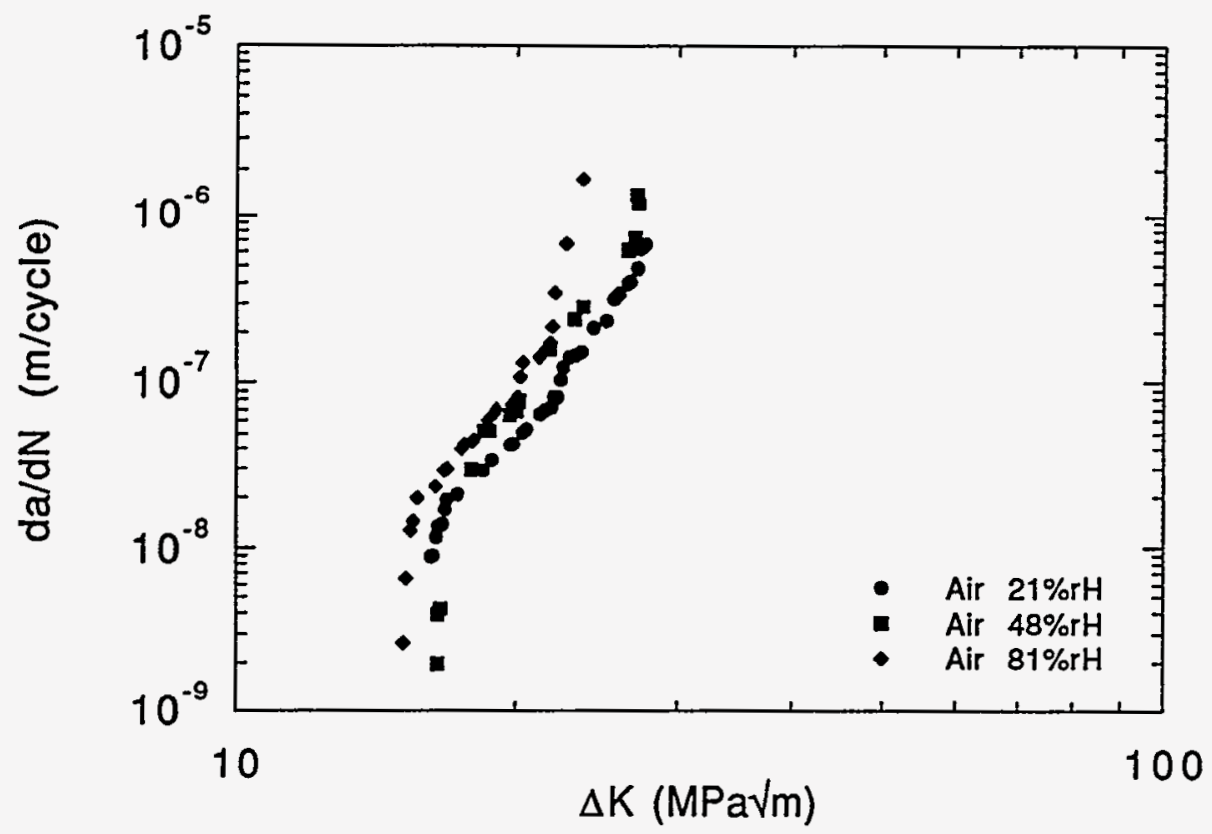

Fig. 3.14. Fatigue Crack Growth Curves for the $1 \% \mathrm{ZrC}$ Alloy at $25^{\circ} \mathrm{C}$.

\subsubsection{Effect of Frequency}

The effect of decreasing the fatigue crack growth frequency for the $0.5 \% \mathrm{ZrC}$ alloy is shown in Fig. 3.15. All tests were run at a constant humidity level of $21 \%$ rH. Also shown is the fatigue test conducted in oxygen which is considered the inert environment for determining the magnitude of crack growth enhancement.

As can bee seen in Fig. 3.15 the lower frequencies enhance fatigue crack growth, as well as having a significant affect on both the threshold and critical stress intensities.

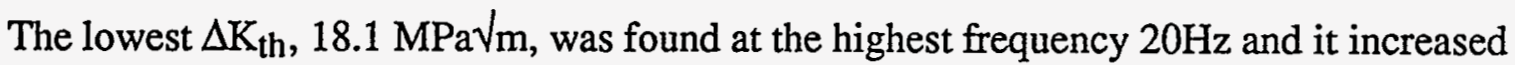
to $24.1 \mathrm{MPa} / \mathrm{m}$ at $0.08 \mathrm{~Hz}$. The critical stress intensity decreased as the frequency was increased. $\Delta \mathrm{K}_{\mathrm{c}}$ dropped from $59.1 \mathrm{MPa} V_{\mathrm{m}}$ to $33.1 \mathrm{MPa} V_{\mathrm{m}}$ between $20 \mathrm{~Hz}$ and $0.2 \mathrm{~Hz}$. The increase in $\Delta \mathrm{K}_{\mathrm{c}}$ between $0.2 \mathrm{~Hz}$ and $0.08 \mathrm{~Hz}$ from $33.1 \mathrm{MPa} ل_{\mathrm{m}}$ to $35.8 \mathrm{MPa} \sqrt{\mathrm{m}}_{\mathrm{m}}$ is not significant because it is within the experimental error. 


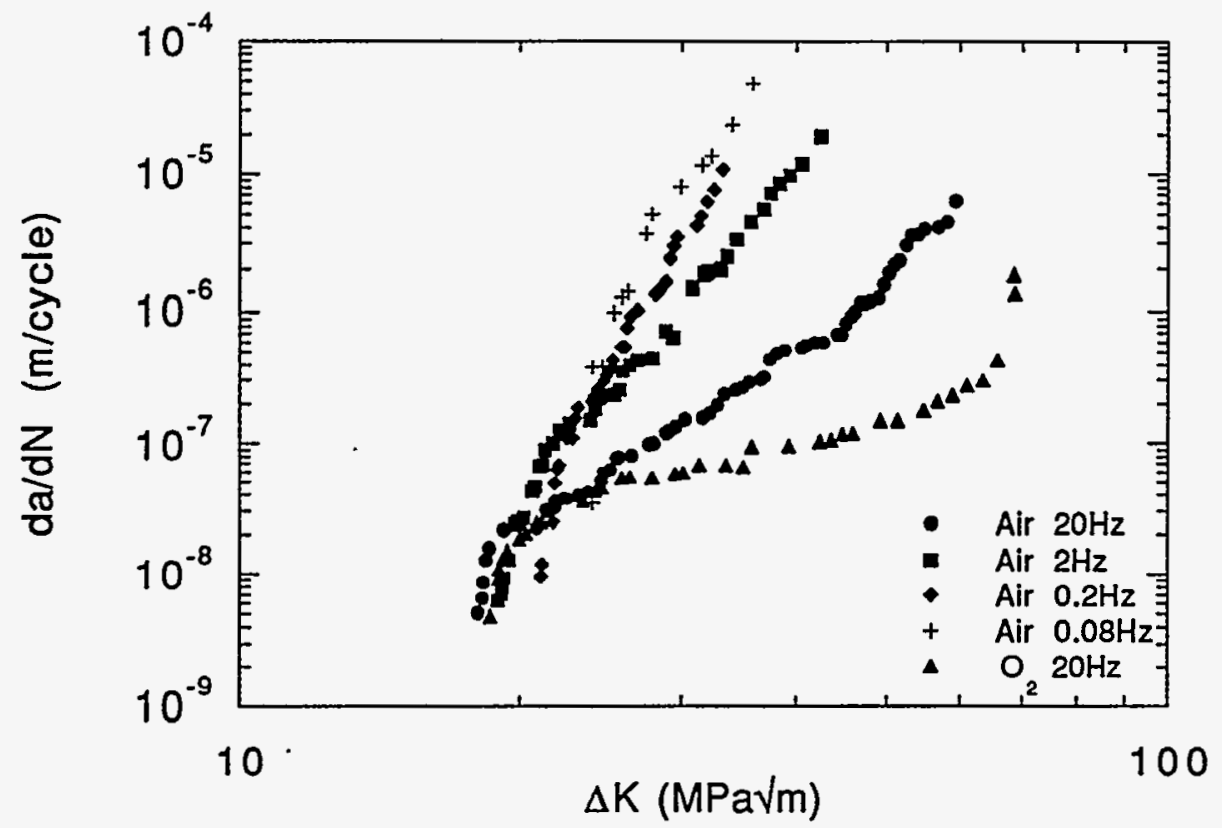

Fig. 3.15. Effect of Frequency on the $0.5 \% \mathrm{ZrC}$ Alloy in $21 \% \mathrm{rH}$ Air at $25^{\circ} \mathrm{C}$.

\subsection{Transmission Electron Microscopy}

TEM foils from the fatigued region of the alloys tested in air were examined to determine the dislocation structure, as well as the precipitate morphology. The ternary alloy exhibited no precipitates while the dislocation structure was similar to that found by previous research $(6,7)$. The structure consist of loosely coupled single dislocations along with a cellular subgrain structure (see Fig. 3.16). The walls of the subgrain are made up of a rectangular array of dislocations.

The $0.5 \% \mathrm{Zr}$ alloy exhibited few subgrains with small precipitates $(0.3 \mu \mathrm{m}$ diameter) located along grain boundaries (see Fig. 3.17a). The precipitates were found to be $\mathrm{Zr}$-rich as EDS showed (see Fig. 3.17b). The subgrain walls are also composed of a rectangular array of dislocations.

Fig. 3.18a shows the dislocation structure and precipitates in $0.5 \% \mathrm{ZrC}$. The small precipitates ( $0.2 \mu \mathrm{m}$ diameter) were found to be $\mathrm{Zr}$-rich ( see Fig. 3.18b) and to lie along 
grain boundaries. $0.5 \% \mathrm{ZrC}$ exhibited more subgrains than $0.5 \% \mathrm{Zr}$ along with more complex dislocation arrays.

$1 \% \mathrm{ZrC}$ exhibits much larger $\mathrm{Zr}$-rich precipitates ( $3 \mu \mathrm{m}$ diameter) that are located along the grain boundaries (see fig. 3.19a). The precipitates sometimes form into a band along the grain boundaries, such as in Fig. 3.19b. Few subgrains were found in $1 \% \mathrm{ZrC}$ while there were many single and some paired dislocations.

\section{DISCUSSION}

The increased tensile elongation of the ternary alloy in oxygen as compared to air demonstrates the embrittling effect of moisture in laboratory air, which is consistent with previous findings on $\mathrm{Fe}_{3} \mathrm{Al}, \mathrm{Cr}(8,9)$. The $0.5 \% \mathrm{ZrC}$ alloy exhibits similar elongations in air and oxygen while the elongation is reduced in hydrogen. For the $\mathrm{Zr}$-containing alloys the elongation is reduced when the $\mathrm{C}$ is removed and further reduced when the $\mathrm{Zr}$ content is increased to $1 \mathrm{a} \%$ with the $\mathrm{C}$ content maintained at $0.05 \mathrm{a} \%$. This suggests that a small amount of $\mathrm{Zr}$ can increase the intrinsic ductility of $\mathrm{Fe}_{3} \mathrm{Al}, \mathrm{Cr}$ alloys.

The fatigue crack growth behavior of all alloys clearly show the embrittling effect of hydrogen whether it is present as hydrogen gas or water vapor in air. The lowest crack growth rates were found in oxygen for all alloys. The difference in critical stress intensity in the $\mathrm{Zr}$-containing alloys between air and oxygen (about $21 \%$ ) was much less than in the ternary alloy (36\%) which indicates that $\mathrm{Zr}$-containing alloys are less susceptible to moisture-induced embrittlement.

The increase in fatigue crack growth rate with decreased frequency further indicates the susceptibility to embrittlement. It is interesting to note that the rate decreases drastically between $20 \mathrm{~Hz}$ and $2 \mathrm{~Hz}$ while between $2 \mathrm{~Hz}$ and $0.08 \mathrm{~Hz}$ the decrease is much less drastic. The threshold stress intensity was found to increase with decreased frequency with the difference being greater between $0.08 \mathrm{~Hz}$ and $2 \mathrm{~Hz}$ than $2 \mathrm{~Hz}$ and $20 \mathrm{~Hz}$. 
The threshold stress intensities are affected by $\mathrm{Zr}$ additions. The addition of $1 \mathrm{a} \%$ $\mathrm{Zr}$ is only beneficial in hydrogen; in all other environments there is no difference when compared to the ternary alloy. In air and in hydrogen $0.5 \mathrm{a} \% \mathrm{Zr}$ raises the threshold stress intensity by $6 \%$ and $28 \%$ respectively, while in oxygen it lowers the threshold stress intensity by $23 \%$ when compared to the ternary alloy.

$\mathrm{Zr}$ additions were found to be beneficial in reducing the susceptibility to moistureinduced embrittlement. Alloying with $1 \mathrm{a} \% \mathrm{Zr}$ reduced the reduced the detrimental effect of increased moisture content during testing. The stress intensity necessary to reach $10^{-7}$ $\mathrm{m} /$ cycle differed by $11 \%$ in $1 \% \mathrm{ZrC}$ between $21 \% \mathrm{rH}$ and $81 \% \mathrm{rH}$ as compared to $16 \%$ for $0.5 \% \mathrm{ZrC}$. The addition of $\mathrm{C}$ had a negligible effect on the susceptibility to moistureinduced embrittlement.

An interesting effect of the addition of $\mathrm{Zr}$ was on the fatigue crack growth resistance in hydrogen. In all $\mathrm{Zr}$-containing alloys the threshold stress intensity is higher in hydrogen gas than in air while the crack growth rate is much higher. The threshold stress intensity also exhibits no change from oxygen to hydrogen for all $\mathrm{Zr}$-containing alloys .

The low crack growth rates in the $0.5 \% \mathrm{Zr}$ alloys were the most surprising results of this investigation. An explanation by which $\mathrm{Zr}$ affects the crack growth rate appears to be as a grain boundary strengthener and a trap for $\mathrm{H}$ so that the latter cannot reach the crack-tip region. The addition of $0.5 \mathrm{a} \% \mathrm{Zr}$ results in a change from mixed transgranular cleavage and intergranular fracture to transgranular tearing, which points to an increase in the strength of grain boundaries. The TEM studies show that when $\mathrm{Fe}_{3} \mathrm{Al}$ is alloyed with $\mathrm{Zr}, \mathrm{Zr}$-rich precipitates form along the grain boundaries. It was also found that as the alloying amount of $\mathrm{Zr}$ is increased the precipitates become larger and form bands of $\mathrm{Zr}$ rich veins along the grain boundaries.

The evidence for the trapping of $\mathrm{H}$ by the $\mathrm{Zr}$-rich precipitates is found in the $1 \mathrm{a} \%$ $\mathrm{Zr}$ alloy. In the case of $1 \% \mathrm{ZrC}$ some intergranular facets appeared only in 


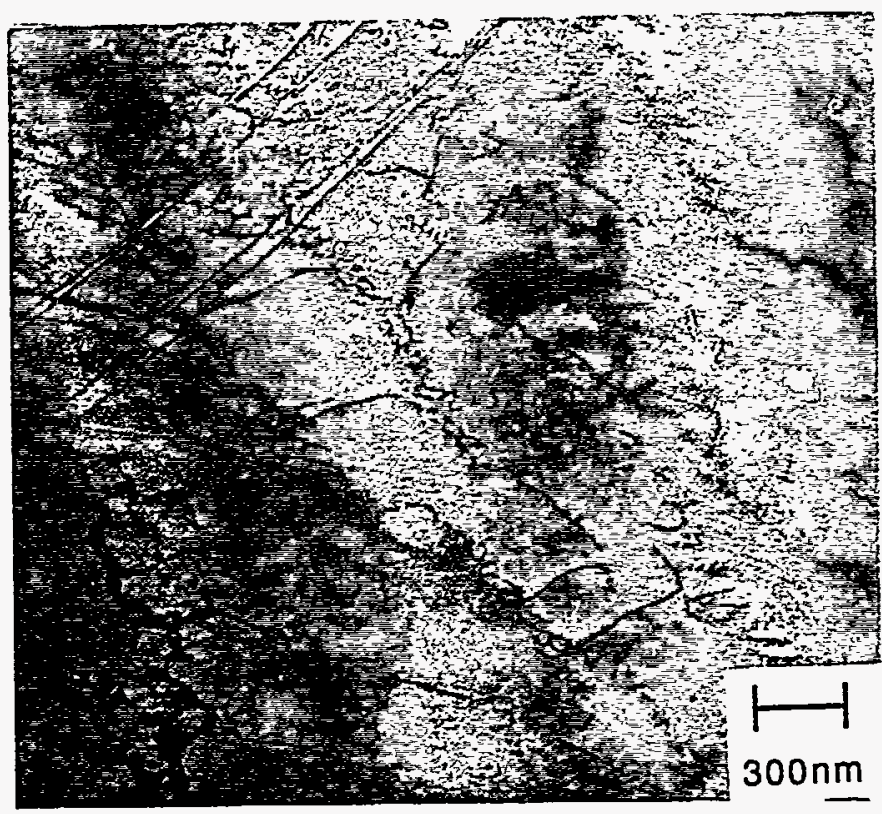

Fig. 3.16. Dislocation structure of the Ternary alloy fatigued in air at $25^{\circ} \mathrm{C}$ 


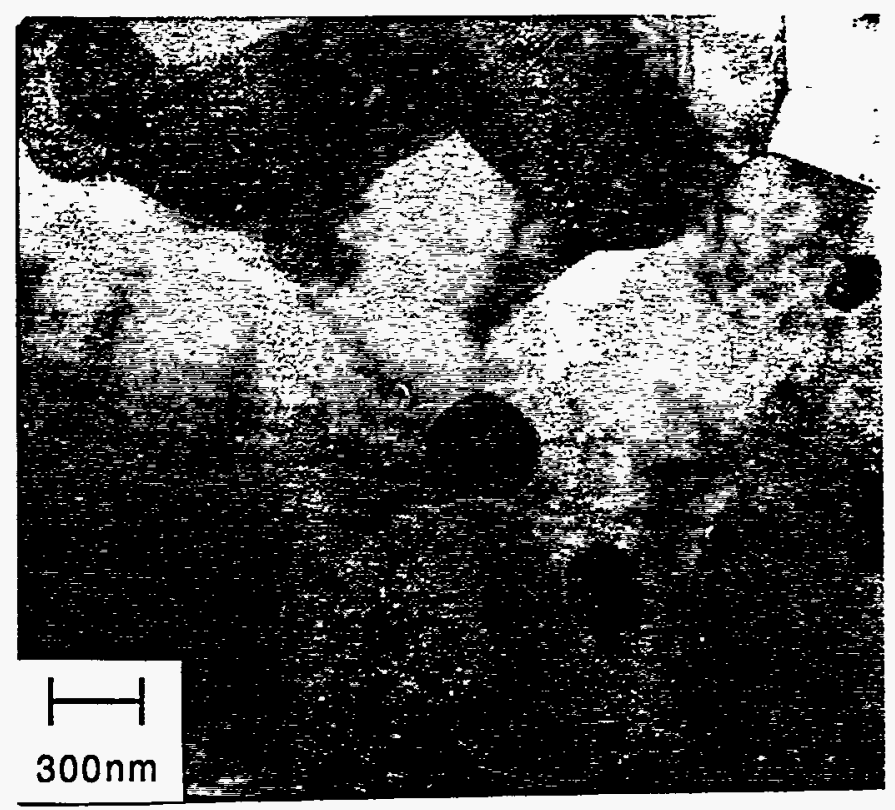

(a)

Tiv-5500

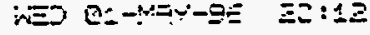

Cursor: 0.000ke: =0

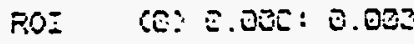

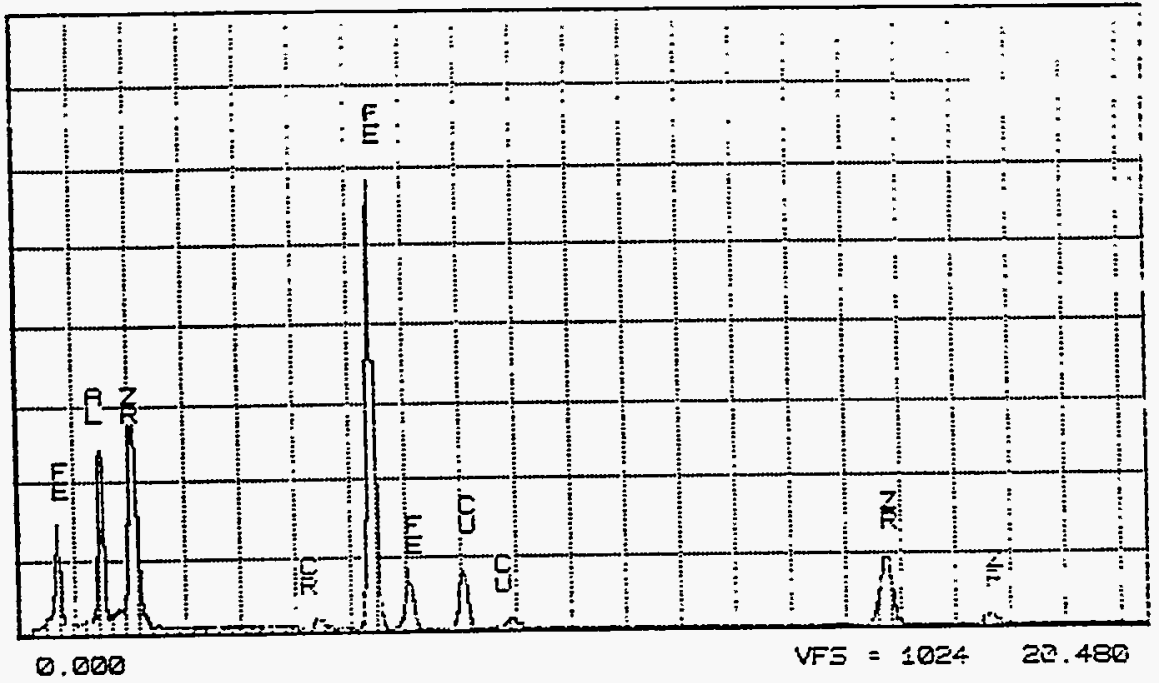

(b)

Fig. 3.17. Dislocation structure of $0.5 \% \mathrm{Zr}$ fatigued in air at $25^{\circ} \mathrm{C}$ (a) and EDS of precipitate(b). 


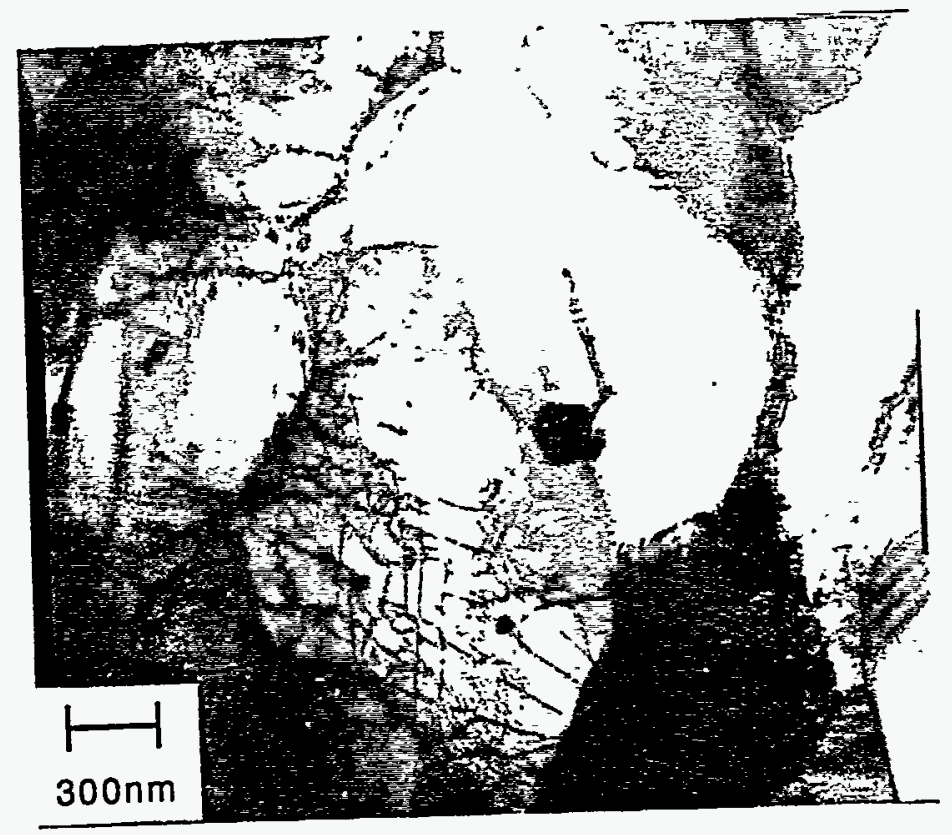

(a)

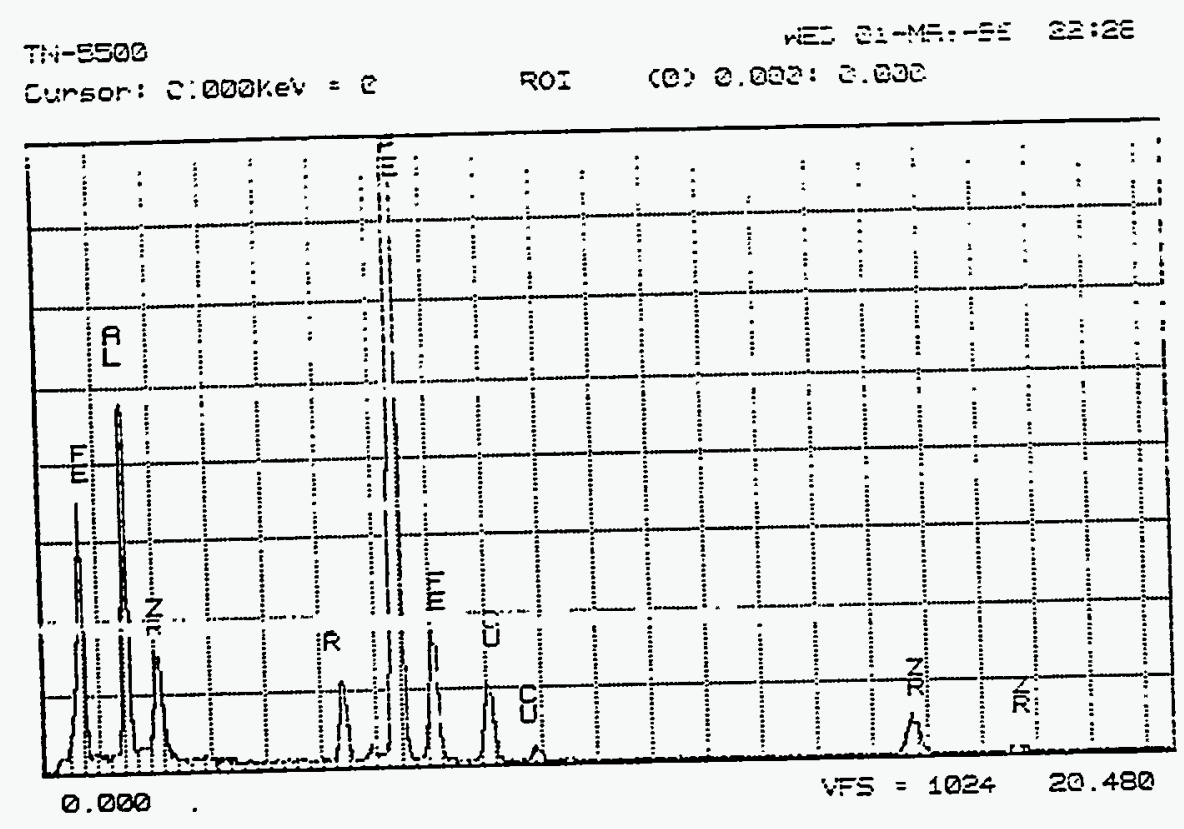

(b)

Fig. 3.18. Dislocation structure of $0.5 \% \mathrm{ZrC}$ fatigued in air at $25^{\circ} \mathrm{C}$ (a) and EDS of precipitate(b). 


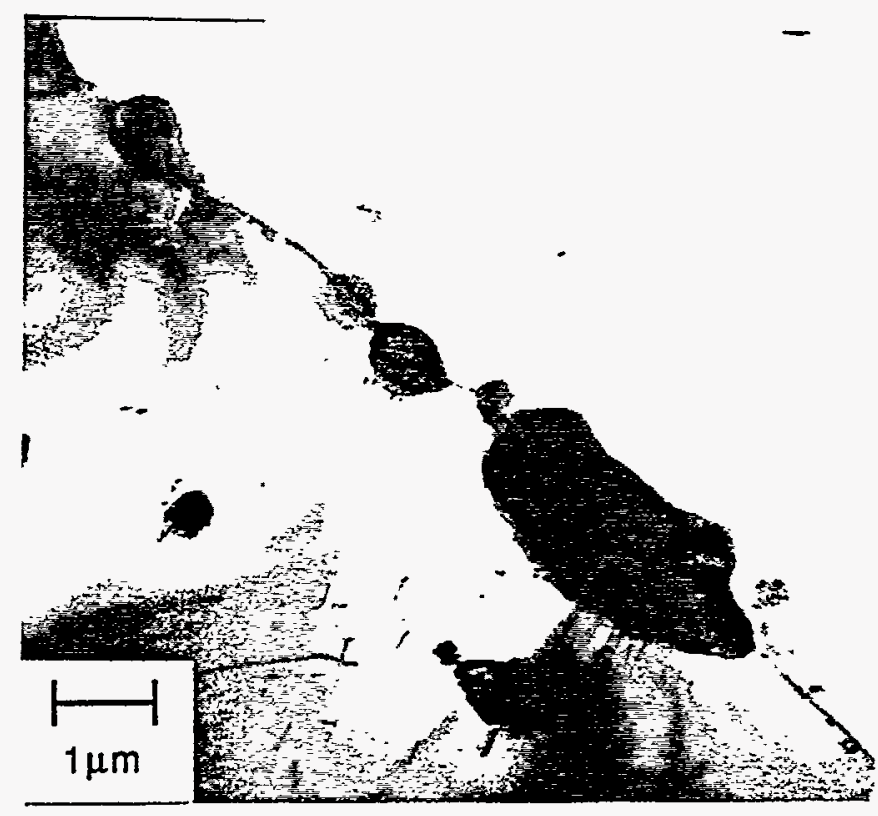

(a)

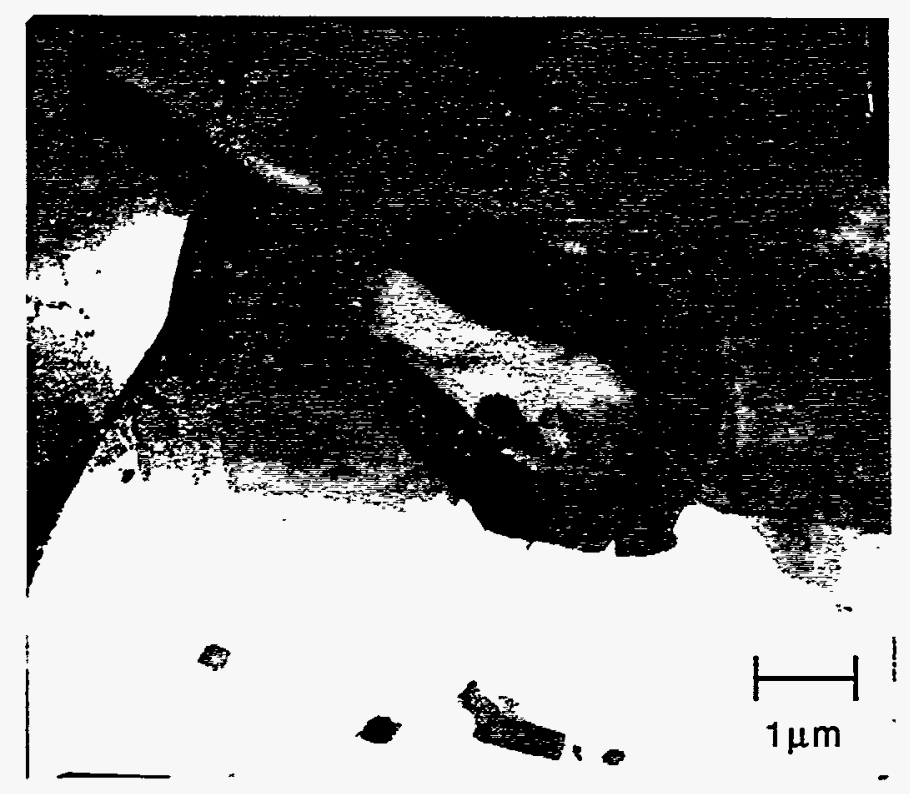

(b)

Fig. 3.19. Dislocation structure of $1 \% \mathrm{ZrC}$ fatigued in air at $25^{\circ} \mathrm{C}$ (a) precipitate band along grain boundary(b). 
hydrogen-containing environments while the failure mode was completely transgranular tearing in inert environments. This points to the fact that $\mathrm{H}$ segregates to the precipitates along the grain boundaries and when the concentration becomes great enough failure is initiated at the grain boundary as opposed to the cleavage plane.

\section{CONCLUSIONS}

The addition of small amounts of $\mathrm{Zr}$ to $\mathrm{Fe}_{3} \mathrm{Al}, \mathrm{Cr}$ alloys results in lower crack growth rates. The beneficial effect of $Z r r$ is limited to very low concentrations, since the addition of $1 \mathrm{a} \% \mathrm{Zr}$ results in higher crack growth rates, similar to those for the ternary alloy. The beneficial effect was found to be due to the formation of small $\mathrm{Zr}$-rich precipitates along the grain boundaries which strengthen the grain boundaries and trap $\mathrm{H}$ during fatigue crack growth. The addition of $\mathrm{C}$ appears to only affect the fracture toughness of $\mathrm{Fe}_{3} \mathrm{Al}, \mathrm{Cr}$ alloys. $\mathrm{Zr}$ additions also result in increased threshold values in hydrogen when compared to air, while the crack growth rate at higher $\Delta \mathrm{K}$ was higher in hydrogen.

\section{ACKNOWLEDGEMENTS}

The authors are grateful to the Department of Energy, Fossil Energy Program for providing financial support under Martin Marietta Energy Subcontract No. 19X-SF521C. The authors are also grateful for helpful discussions with Dr. V. K. Sikka of ORNL and to Dr. Sikka for providing the alloys. 


\section{REFERENCES}

1. C. T. Liu, E. H. Lee and C. G. McKamey, Scr. Metall., vol. 23, pp. 875-880 (1989).

2. A. Castagna, Ph.D. Thesis, Rensselaer Polytechnic Institute (1995).

3. A. Castagna, P. J. Maziasz and N. S. Stoloff, Influence of Environment on Crack Growth Resistance of an $\mathrm{Fe}_{3} \mathrm{Al}, \mathrm{Cr}$ Alloy, I. Baker, R. Darolia, J. D.

Whittenberger, M. H. Yoo, Eds., High Temperature Ordered Intermetallic Alloys V (MRS Symp. Proc., Pittsburgh, 1993), vol. 288, pp. 1043-1048.

4. ASTM, in 1993 Annual Book of ASTM Standards(ASTM, Philadelphia, Pa., 1993), vol. 03.01, pp. 569-596.

5. C. G. McKamey and D. H. Pierce, Scr. Metall., vol. 28, pp. 1173-1176 (1993).

6. D. G. Morris and M. Leboeuf, Acta Metall., vol. 42, pp. 1817-1823 (1994).

7. D. G. Morris, M. M. Dadras and M. A. Morris, Acta. Metall. Mater., vol. 41, pp. 97-111 (1993).

8. C. G. McKamey, J. A. Horton and C. T. Liu, J. Mater. Res., vol. 4, pp. 1156-1163 (1989).

9. C. G. McKamey and C. T. Liu, Scr. Metall., vol. 24, pp. 2119-2122 (1990). 
AIR PRODUCTS AND CHEMICALS

P.O. Box 538

Allentown, PA 18105

S. W. Dean

ALBERTA RESEARCH COUNCIL

Oil Sands Research Department

P.O. Box 8330, Postal Station F

Edmonton, Alberta

Canada T6H5X2

L. G. S. Gray

\section{ALLISON GAS TURBINE DIVISION}

P.O. Box 420

Indianapolis, IN 46206-0420

P. Khandelwal (Speed Code W-5)

R. A. Wenglarz (Speed Code W-16)

AMAX R\&D CENTER

5950 McIntyre Street

Golden, CO 80403

T. B. Cox

ARGONNE NATIONAL LABORATORY

9700 S. Cass Avenue

Argonne, IL 60439

W. A. Ellingson

ARGONNE NATIONAL LABORATORY-WEST

P.O. Box 2528

Idaho Falls, ID 83403-2528

S. P. Henslee

\section{BABCOCK \& WILCOX}

Domestic Fossil Operations

20 South Van Buren Avenue

Barberton, $\mathrm{OH} 44023$

M. Gold

\author{
BETHLEHEM STEEL CORPORATION \\ Homer Research Laboratory \\ Bethlehem, PA 18016 \\ B. L. Bramfitt \\ J. M. Chilton
}

BRITISH COAL CORPORATION

Coal Technology Development Division

Stoke Orchard, Cheltenham

Glocestershire, England GL52 4ZG

J. Oakey
CANADA CENTER FOR MINERAL \& ENERGY TECHNOLOGY

568 Booth Street

Ottawa, Ontario

Canada K1A OG1

R. Winston Revie

Mahi Sahoo

COLORADO SCHOOL OF MINES

Department of Metallurgical Engineering

Golden, CO 80401

G. R. Edwards

DOE

DOE OAK RIDGE OPERATIONS

P. O. BOX 2008

Building 4500N, MS 6269

Oak Ridge, TN 37831

M. H. Rawlins

DOE

DOE OAK RIDGE OPERATIONS

P. O. Box 2001

Oak Ridge, TN 37831

Assistant Manager for

Energy Research and Development

DOE

IDAHO OPERATIONS OFFICE

P. O. Box 1625

Idaho Falls, ID 83415

J. B. Malmo

DOE

MORGANTOWN ENERGY TECHNOLOGY

CENTER

P.O. Box 880

Morgantown, WW 26505

R. C. Bedick

D. C. Cicero

F. W. Crouse, Jr.

R. A. Dennis

N. T. Holcombe

W. J. Huber

T. J. McMahon

J. E. Notestein 


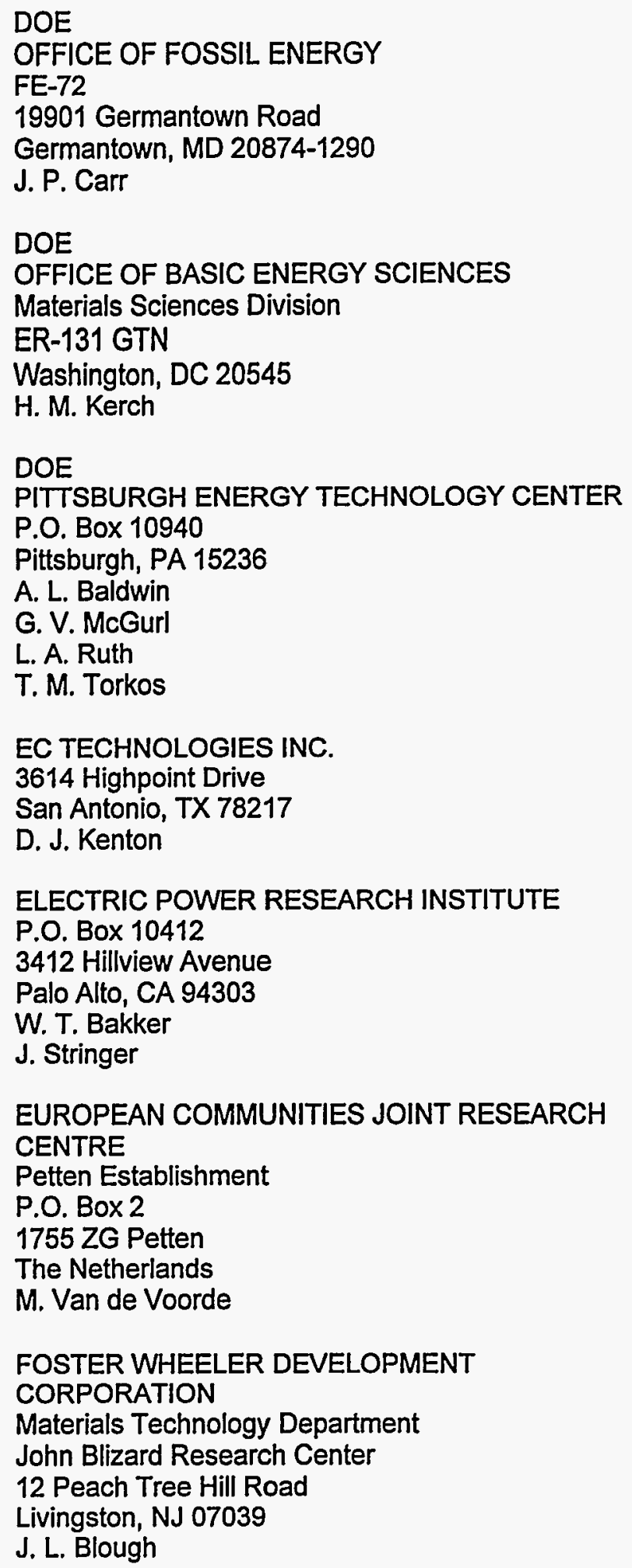

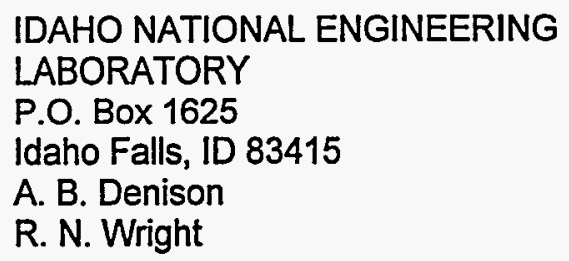

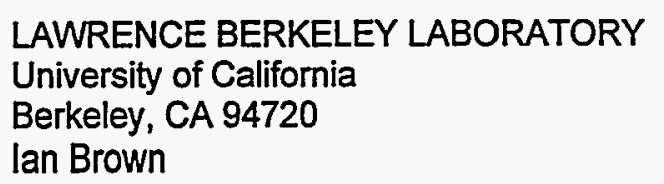

NATIONAL MATERIALS ADVISORY BOARD National Research Council 2101 Constitution Avenue Washington, DC 20418 K. M. Zwilsky

OAK RIDGE NATIONAL LABORATORY P.O. Box 2008

Oak Ridge, TN 37831

P. T. Carlson

N. C. Cole

G. M. Goodwin

F. D. Johnson (5 copies)

R. R. Judkins

C. T. Liu

C. G. McKamey

V. K. Sikka

R. W. Swindeman

P. F. Tortorelli

M. R. Upton

I. G. Wright 
PACIFIC NORTHWEST LABORATORY

P. O. Box 999, K3-59

Battelle Boulevard

Richland, WA 99352

R. N. Johnson

SHELL DEVELOPMENT COMPANY

P. O. Box 1380

Houston, TX 77251-1380

L. W. R. Dicks

THE JOHNS HOPKINS UNIVERSITY

Materials Science \& Engineering

Maryland Hall

Baltimore, MD 21218

R. E. Green, Jr.

THE MATERIALS PROPERTIES COUNCIL, INC.

United Engineering Center

345 E. Forty-Seventh Street

New York, NY 10017

M. Prager

THE TORRINGTON COMPANY

Advanced Technology Center

59 Field Street

Torrington, CT 06790

W. J. Chmura

UNION CARBIDE CORPORATION

Linde Division

P.O. Box 44

175 East Park Drive

Tonawanda, NY 14151-0044

Harry Cheung

UNIVERSITY OF WASHINGTON

Department of Materials Science

and Engineering

101 Wilson, FB-10

Seattle, WA 98195

T. G. Stoebe

UNIVERSITY OF TENNESSEE AT KNOXVILLE

Materials Science and Engineering

Department

Knoxville, TN 37996

P. Liaw

C. D. Lundin
WESTERN RESEARCH INSTITUTE

365 N. 9th Street

P.O. Box 3395

University Station

Laramie, WY 82071

V. K. Sethi 